\title{
PRINCIPIO ACUSATORIO: ¿PRESUPUESTO CONSTITUCIONAL DEL PROCEDIMIENTO PENAL EN COLOMBIA?*
}

Lizbeth Barrera Rodríguez

\section{Resumen}

Las múltiples reformas legislativas realizadas en varios países de Latinoamérica y Europa han tenido, como principal propósito, incorporar la estructura del sistema penal adversarial de Estados Unidos y con él, algunos de sus principios esenciales. Dentro de tales elementos, el principio acusatorio se erige como el más importante; pero, al mismo tiempo, es aquel que más imprecisiones conceptuales tiene. Determinar el concepto y el alcance preciso del principio acusatorio es una tarea fundamental para analizar si éste es un presupuesto constitucional necesario del procedimiento penal en Colombia o si, por el contrario, es simplemente una elección legislativa.

\section{Palabras clave}

Imparcialidad judicial, sistema acusatorio, sistema adversarial norteamericano, sistema inquisitivo, principio acusatorio.

\begin{abstract}
Several recent legislative reforms in many Latin American and European countries were aimed to incorporate the United States of America's adversarial criminal justice system and some of its essential principles. The adversarial principle stands as the most important of all, but it has also many conceptual inaccuracies. In order to clarify if the above mentioned principle is a constitutional requisite of the Colombian criminal proceedings or, instead, a merely legislative decision, it is needed to precise its concept and scope.
\end{abstract}

\section{Keywords}

Judicial impartiality, adversarial system, inquisitorial system, adversarial principle, criminal proceedings.

\section{Introducción}

Los valores culturales, sociales y políticos de una comunidad determinan, en cierta forma, la elección de un específico sistema procesal penal (Bovino, 2001a). No puede desconocerse, hoy, que

\footnotetext{
*El presente trabajo se corresponde con la investigación realizada por la autora para optar al título de Maestra en Derecho de la Universidad Sergio Arboleda, Bogotá, Colombia.

** Abogada, Especialista en Derecho Penal y Maestra en Derecho.
} 
la elección de un proceso judicial como aquel instrumento para la aplicación del derecho penal -y la consecuente imposición de una sanción de igual naturaleza- es una decisión política [llamada 'política procesal' por Alcalá-Zamora (1992)]; es la convicción de que el proceso es el mejor instrumento para garantizar la legalidad de la condena la que motiva al Estado a decidir, desde una perspectiva política, dicha elección (Montero, 1994).

Como dice Montero Aroca (1994, 2006), la aplicación del derecho penal sólo puede explicarse a través de la existencia de una serie de límites -o, como él mismo los llama, 'monopolios' - que deben presentarse de manera conjunta y escalonada. El último de tales monopolios [siendo los primeros la prohibición general de autotutela -monopolio estatal-; y la prohibición de que el derecho penal sea aplicado por órganos distintos a los jurisdiccionales -monopolio judicial- (AlcaláZamora y Castillo, 1992)] es aquel que se centra en señalar que el derecho penal debe ser aplicado, de manera exclusiva, por los tribunales a través de un proceso, y no de cualquier otra manera -monopolio procesal- (Montero, 1994, 2006). Los tres monopolios actúan de manera conjunta: sólo el Estado a través de un órgano jurisdiccional, y a través de un proceso penal, puede aplicar el derecho penal como titular del ius puniendi.

Casi todos los procedimientos penales en América Latina, y gran parte de Europa, se han visto contagiados por un tendencia reformadora que busca solucionar los graves problemas de aplicación del derecho penal que sufre cada país, a través del análisis y la aplicación del sistema adversarial norteamericano (Carbonell y Ochoa, 2009; Gómez, 2007; Pérez, 2001; Zepeda, 2005) o del proceso acusatorio, que viene a ser interpretado como lo mismo (Montero, 2009); 'lo acusatorio $^{1}$ se ha cimentado como la bandera que ha de generar cualquier reforma legislativa en materia procesal penal hoy (Bachmaier, 2009; Montero, 2009). Por ello, no es extraño que la introducción de la Ley 906 del 2004 en Colombia (así como la reforma constitucional llevada a cabo en el 2002), tuviera como principal pretensión incorporar figuras procesales propias de dicho sistema procesal (Díaz, 2014; Molina, 2010).

Dentro de tales pretensiones era clara aquella de incluir dentro del procedimiento penal colombiano el principio acusatorio, del que el sistema adversarial se edificaba (Díaz, 2014). Las modificaciones procesales a lo largo de América Latina y Europa se encuentran motivadas por la incorporación del llamado principio acusatorio a los distintos procedimientos penales nacionales (Gómez, 2007; Montero, 2009; Pérez, 2001): el proceso penal norteamericano, se dice, se funda en el principio acusatorio y regula un auténtico juicio oral y público, de donde deducen los países afectados por las reformas de su proceso penal en profundidad que esos estandartes tienen que ser también los suyos (Gómez, 2007, p. 76).

${ }^{1}$ A lo largo del texto, se utilizará la expresión 'lo acusatorio' entendido como un concepto difuso, sin límites ni elementos claros, utilizándolo de la misma manera que Montero (2009). También se utilizará la expresión 'lo inquisitivo'. 
A pesar de la pretendida necesidad de incorporar el principio acusatorio en nuestro ordenamiento, es claro que en la doctrina y en la jurisprudencia existe confusión sobre el concepto y el alcance preciso del principio acusatorio (González, 2001; Montero, 2006, 2009). El derecho procesal penal es la reglamentación del derecho constitucional (Bovino, 1998), en el sentido de que el legislador se encuentra sometido a los principios rectores establecidos por la Constitución Política al momento de establecer el procedimiento penal por medio del cual aplicará el derecho penal (Bovino, 1998). Hablar de derecho procesal penal (y de procedimiento penal) es referirse a la aplicación de ciertas garantías procesales que pueden o no tener origen constitucional; si tienen tal origen, su aplicación e incorporación en la ley será obligatoria para el legislador; si no, su reglamentación procedimental dependerá de una decisión político-criminal del legislador.

Frente a este escenario, y contemplando la importancia que tuvo para el legislador el principio acusatorio al momento de la promulgación de la Ley 906 del 2004, es razonable preguntarse si tal principio se encuentra reconocido en nuestra Constitución (y por ende, el legislador no puede desconocerlo) o, si por el contrario, la consagración de tal garantía en el procedimiento penal es una alternativa político-criminal opcional que puede hacer el legislador. De allí que el problema jurídico por resolver en este artículo gire alrededor de la siguiente pregunta: ¿es el principio acusatorio un presupuesto que condiciona la constitucionalidad del proceso penal en Colombia? El problema planteado, como puede verse, parte de establecer si el principio acusatorio es un presupuesto constitucional del proceso penal en Colombia, una garantía procesal obligatoria cuya omisión podría generar una vulneración de derechos fundamentales en el procedimiento judicial penal.

Para resolver este problema jurídico se debe hacer un análisis escalonado en tres partes: la primera, busca indagar las diferencias establecidas por la doctrina entre los llamados procesos acusatorios e inquisitivos, en la medida en que de dichas diferencias pueden deducirse elementos de análisis que permitan identificar y precisar el concepto del principio acusatorio, su contenido y sus consecuencias o presupuestos procesales, los cuales aparecen en la segunda parte de este trabajo. En la tercera y última parte se verificará si tal principio es un presupuesto o una exigencia constitucional necesaria en el proceso penal colombiano, a cuyo efecto se examinará la jurisprudencia nacional, analizando la Constitución Política de Colombia y el bloque de constitucionalidad. Se intentará, pues, responder si el principio acusatorio es un elemento necesario -desde una perspectiva constitucional- del proceso penal colombiano.

\section{Diferencias entre 'lo acusatorio' y 'lo inquisitivo'}

Con ocasión de las recientes modificaciones en los sistemas procesales penales latinoamericanos -atendiendo el contenido del sistema adversarial norteamericano- (Carbonell y Ochoa, 2009; Zepeda, 2005), se ha establecido como prioritario determinar, con algo de precisión, las diferencias entre un proceso acusatorio y uno inquisitivo; se hacen esfuerzos académicos por diferenciar, desde el plano teórico, tales procedimientos procesales (Montero, 2009). Y ello puesto 
que se habla, de manera reiterada en Colombia, de la incorporación de un sistema de tendencia acusatoria con la introducción de la Ley 906 del 2004 (Díaz, 2014; Molina, 2010; Montañés, 2001).

¿En qué consisten, pues, estos llamados sistemas acusatorios e inquisitivos? Pese a que la utilización de ambos conceptos no es unívoca (Bachmaier, 2009; Maier, 2001; Montero, 2009), tiende a pensarse que la oposición entre un proceso acusatorio y un proceso inquisitivo responde, de igual manera, a una evolución histórica del proceso penal de un escenario a otro (Carbonell y Ochoa, 2009); se parte de la existencia de principios disímiles entre dichos sistemas procesales a efectos de caracterizarlos y contrastarlos (Anitua, 2009; Carbonell y Ochoa, 2009; Ferrajoli, 1995; Langer, 2001), a manera de principios que estructuran cada sistema pero, a la vez, lo contraponen al otro (González, 2001).

Sin embargo, centrarse sólo en el estudio de tales 'principios alternativos' -que caracterizan cada sistema y lo diferencian- puede considerarse un error (Montero, $1994,2006,2008,2009$ ) a pesar de las voces que afirman que tales sistemas procesales se diferencian con claridad (Iñiguez, 2003; Zamora, 2009); se habla, incluso, de viejas prácticas inquisitivas (Anitua, 2009, p. 1) o una actitud inquisitiva (González, 2001, p. 107).

Es notorio cómo la doctrina maneja los conceptos de sistema acusatorio e inquisitivo como dos opuestos valorativos, en el sentido de que todas las connotaciones procesales negativas se aglutinan en el llamado sistema inquisitivo [se le llega incluso a calificar como censurable (Briseño, s.f.), desarrollando características indeseables (Zamora-Pierce, 1993)], mientras todas las figuras procesales valoradas positivamente [proceso ideal, incluso calificado como garantista (Montañez, 2013)] son incorporadas dentro del sistema acusatorio (Armenta, 2004; Bachmaier, 2009; Bovino, 2001a; Ferrajoli, 1995; Langer, 2001; Maier, 1989; Montero, 2009), a modo de opuestos procesales que conviven en un momento histórico (Bachmaier, 2009; Bovino, 1997, 2001a; Langer, 2001):

La constante confusión entre ambos planos tiene su origen en que, tradicionalmente, el término acusatorio ha tenido un signo positivo, relacionado con una concepción del proceso penal respetuosa de las libertades individuales y asociada a un modelo de Estado liberal o democrático. Lo inquisitivo, por su parte, ha tenido el signo opuesto, siendo asociado con un tipo de proceso penal y de Estado de carácter autoritario (Langer, 2001, p. 16). Incluso, se ha querido mostrar una igualdad entre la oposición acusatorio-inquisitorio en relación con el sistema adversarial norteamericano y el sistema continental europeo -y aquellos procedimientos latinoamericanos con origen inmediato en dicho sistema- (Anitua, 2009; Armenta, 2004; Bovino, 1997, 2001a; Carbonell y Ochoa, 2009; Cuéllar, Ferrera, López, Gómez y Fernández (2004); Damaska, 1998; Iñiguez, 2003; Langer, 2001; Montañez, 2013; Zepeda, 2007), sin explicar con claridad en qué consiste dicha asimilación de conceptos entre lo acusatorio y lo adversarial. Se habla de una dicotomía entre lo adversarial-acusatorio y lo continental-inquisitivo, respecto 
del procedimiento penal (Langer, 2001), aunque existen esfuerzos teóricos por separar dichos conceptos a efectos de no confundir lo acusatorio con lo adversarial (Rodríguez, 2013).

Lo primero que debe contestarse, en este punto, es la aparente similitud entre el sistema adversarial norteamericano con el sistema acusatorio: ¿son sinónimos o acaso dos conceptos diferentes que expresan, en el fondo, el mismo contenido procesal? Bovino (1997, 2001a) afirma que el procedimiento estadounidense es representante de un sistema acusatorio formal acabado, entendiendo por formal aquel sistema en el cual las funciones de indagación y de juzgamiento se encuentran en cabeza de diferentes órganos (Bovino, 2001a; Maier, 1989)². Por su parte Armenta (2004); Anitua (2009) y Damaska (1998), realizan la misma asimilación práctica, equiparando el sistema adversarial norteamericano con el sistema acusatorio.

Pero, más allá de ello, no se explica por qué sólo el sistema adversarial norteamericano es un sistema acusatorio y por qué el sistema continental no lo es; esa asimilación entre lo acusatorio-adversarial y lo inquisitivo-continental, al parecer, se da por sentada pues no se tiene claro qué es lo que identifica a un proceso acusatorio y a uno inquisitivo (Damaska, 1998). Incluso, se llega a incongruencias lógicas cuando se excluye la posibilidad de que los sistemas procesales continentales sean acusatorios, y luego se le da al principio acusatorio un contenido que también los sistemas continentales poseen de manera general e indiscutible (Bovino, 2001a).

Se intenta calificar lo adversarial como acusatorio, pero se tilda de inquisitivo (o como no acusatorio, lo que termina siendo calificado como inquisitivo) aquellos mecanismos abreviados de justicia negociada que caracterizan al sistema norteamericano -como el plea bargaining-(Almeyra, 1997; Bovino, 2001b; Montañez, 2013), con lo cual no se da claridad a la dicotomía mantenida entre lo acusatorio y lo inquisitivo en este punto, sino que se llega a una incoherencia conceptual entre lo que se define como acusatorio y lo que en realidad es (Langer, 2001).

Por supuesto, esta confusión lo único que genera es una valoración incorrecta de los sistemas procesales: el sistema adversarial (por ser acusatorio) es valorado positivamente, mientras que el sistema continental europeo (por ser inquisitivo) es valorado negativamente (Damaska, 1998). Si la tradición de Europa continental jugó papel alguno en este desarrollo constitucional, fue apenas en el sentido de constituir un ejemplo negativo: el proceso continental tradicional fue asociado algunas veces con confesiones producidas por medio de la coerción, una búsqueda de pruebas sin control y los horrores de la Santa Inquisición (Damaska, 1998, p. 15).

No se pregunta, ni siquiera, qué caracteriza a cada sistema procesal con el fin de evaluar si, en efecto, el sistema adversarial es tan acusatorio como se afirma y el sistema continental es tan inquisitivo como se pretende; se cree que son dos

${ }^{2}$ Todo esto en contraposición a un sistema acusatorio material, donde además de tener ambas funciones separadas (función de investigación y función de juzgamiento), la primera de estas funciones sólo puede adelantarla una persona particular, no un órgano del Estado (Bovino, 2001a; Maier, 1989). 
sistemas procesales contemporáneos y en lucha constante (Bovino, 1997, 2001a; Damaska, 1998). Lo claro en este punto es que la dicotomía mantenida entre lo acusatorio-adversarial y lo inquisitivo-continental es un enfoque histórico del problema, que ha tenido contenidos diferentes a partir del entendimiento concreto del concepto 'lo acusatorio' y 'lo inquisitivo' (Langer, 2001).

Ahora bien, si no es del todo clara la asimilación acusatorio-adversarial, mucho menos lo es la diferencia inquisitivo-acusatorio mantenida hoy. Si se parte de un enfoque histórico-ideal, contrastando ciertos principios ineluctables de cada sistema para caracterizarlos a modo de "procesos ideales" (Langer, 2001), pueden deducirse varias diferencias que se han querido encontrar entre un sistema procesal acusatorio y uno de carácter inquisitorio: el ejercicio del poder jurisdiccional en cabeza de tribunales populares o jueces permanentes y profesionales; la naturaleza pública o privada de la acción penal; la posición procesal de las partes dentro del proceso (igualdad y contradicción, o desigualdad, siendo el acusado objeto del proceso y no parte de éste); las facultades -amplias o restringidas- del juez en el proceso; la libertad o la detención del acusado; la introducción y valoración de las pruebas; etc. (Cuéllar et al, 2004; Díaz, 2014; Montañez, 2013; Montero, 1994, 2006, 2009). Se habla, incluso, de sistemas procesales que logran, de manera diversa y a través de características y elementos distintos, la consecución de la verdad procesal (Bovino, 2001a).

Se contrasta el proceso inquisitivo con el proceso acusatorio en la medida en que aquel no tiene una distinción clara entre el órgano de juzgamiento y el órgano acusador, mientras el acusatorio se caracteriza por una marcada diferencia entre las partes y un tercero imparcial que debe resolver los hechos que le han puesto en conocimiento (Carbonell y Ochoa, 2009; González, 2001). Incluso, se llega a los extremos de afirmar que en el sistema acusatorio (o adversativo, pues parece ser lo mismo) se da un respeto indiscutible al derecho de igualdad entre las partes, mientras que en el sistema inquisitivo ello no es así (Bovino, 2001a).

Ferrajoli (1995), por su parte, ha establecido que el punto central en la diferencia entre el proceso acusatorio y el inquisitivo son las garantías orgánicas y las garantías procesales que cada uno de tales sistemas reconoce: mientras el primero reconoce la existencia de un juez popular y favorece un juicio contradictorio como medio para conseguir la verdad, el sistema inquisitivo se caracteriza por tener estructuras judiciales burocratizadas y procedimientos regidos por poderes amplios de instrucción de los jueces. A pesar de las diferencias establecidas, es claro que la doctrina que utiliza este enfoque no coincide al momento de determinar cuál es el contenido asignado a cada uno de estos "procesos ideales" (Langer, 2001). Sin embargo, si algo queda claro es que estas discrepancias no dicen nada sobre la real naturaleza del proceso, pues estas diferencias se dirigen a analizar aspectos tangenciales, no esenciales, de ambos sistemas procesales (Montero, 1994, 2006); pese a ello, hay quienes afirman que este ejercicio debe analizarse en términos de utilidad, respecto del fin específico que se propone cada autor al momento de comparar ambos sistemas (Langer, 2001). 
Si el ejercicio de comparar ambos sistemas procesales se evalúa en términos de utilidad -tal como lo afirma Langer (2001)-, aquí se procederá a realizar tal comparación a efectos de intentar otorgar a cada sistema (en especial, al sistema acusatorio) un contenido preciso, del cual puedan deducirse, después, elementos para comprender el principio acusatorio. El proceso inquisitivo se caracteriza, o es caracterizado por la doctrina, como aquel proceso en el que los actos de investigación, acusación y juzgamiento son adelantados por un único órgano (Bachmaier, 2009; Pérez, 2001; Zamora, 1993, 2009) -tal como se aglutinaban todos los poderes del Estado en el soberano único- (Armenta, 2004; González, 2001; Maier, 1989); la investigación y el enjuiciamiento era llevado a cabo por el juez instructor, quien acusaba y resolvía los hechos investigados (Cuéllar et al, 2004; Iñiguez, 2003).

El proceso inquisitivo era secreto (Fernández, 1990; Ferrajoli, 1995; González, 2001; Zamora, 1993), calidad que se predicaba de las necesidades propias de la investigación -por la ausencia de debate procesal- (Maier, 1989); se identifica con una política criminal autoritaria, en contraposición a una de carácter democrático en relación con el sistema acusatorio (Anitua, 2009), proceso claramente contrario a una real contradicción procesal entre las partes (Armenta, 2004). Por ello, es producto histórico de la concepción absoluta del poder central estatal, la idea de la autoridad y la centralización de todos los poderes del Estado en el soberano (Bachmaier, 2009; Maier, 1989), sistema procesal que se originó gracias a la universalidad de la Iglesia Católica y a la formación de los estados-nación durante la Edad Media (Bachmaier, 2009; Maier, 1989); la manifestación más pura y característica del proceso inquisitivo surgió como consecuencia de la adopción de un Estado absolutista (González, 2001).

El proceso inquisitivo surge, entonces, del escaso valor que se le dispensa a la persona humana, reduciéndolo a un simple objeto de investigación (Montañez, 2013) - perdiendo, así, su condición de sujeto de derechos- (Maier, 1989; Zamora, 1993). La persecución penal en el proceso inquisitivo era pública y obligatoria (Cuéllar et al, 2004; Maier, 1989), por lo que se entiende -no sin razón- que el sistema inquisitivo excluyó a la víctima del proceso (Bovino, 1997). Aunque existe alguna doctrina que niega el carácter público de la persecución en el proceso inquisitivo (Ferrajoli, 1995), con lo cual se ponen de presente las discrepancias que se le han asignado al contenido de ambos sistemas procesales.

La decisión final del proceso está en cabeza de un juez profesional -en contraposición con las calidades del juzgador en el sistema acusatorio- (Bachmaier, 2009; Bovino, 2001a; Ferrajoli, 1995; González, 2001); la incorporación de un juez profesional -conocedor de las ciencias jurídicas- ha sido analizada como algo positivo (González, 2001), pero incluso como algo negativo o reprochable, aseverando que la construcción de la verdad procesal varía de un sistema procesal a otro por el carácter profesional del juzgador (Bovino, 2001a). Sin embargo, se llega a afirmar que es el proceso acusatorio el que se identifica con la profesionalización de sus partes, a través de los papeles de solicitors (el procurador encargado de preparar la causa penal), barristers (el abogado litigante) y el prosecutor (el fiscal) (Guerrero, 2006), con lo cual no queda claro cuál es la aparente dicotomía entre 'lo acusatorio' y 'lo inquisitivo' en este punto específico. 
Frente a los medios de prueba, se afirma que las fuentes de conocimiento procesal son introducidas e incorporadas en el proceso por medio escrito -de manera general- (Bachmaier, 2009; Cuéllar et al, 2004; Ferrajoli, 1995; González, 2001), sin contradicción por parte del acusado (Iñiguez, 2003; Maier, 1989), incluyendo una valoración legal o tasada de la misma (Alcalá-Zamora y Castillo, 1992); la actividad probatoria era de exclusivo resorte del juez (Fernández, 1990; Ferrajoli, 1995), siendo el objetivo de la prueba la averiguación de la verdad, aunque ésta podía lograrse a través de cualquier medio posible (Maier, 1989). De hecho, la obtención coercitiva de la culpabilidad es un elemento a través del cual se caracteriza al sistema inquisitivo (Langer, 2001).

Se llega, incluso, a calificar al proceso inquisitivo como aquel que buscaba por excelencia la prueba de confesión de manera coactiva -mediante tortura- (Anitua, 2009; Bachmaier, 2009; Ferrajoli, 1995; Guerrero, 2006; Maier, 1989; Zamora, 1993), caracterizado por ser un sistema de justicia parcializado (Armenta, 2004), fruto de concepciones autoritarias (Zamora, 2009) y sin garantías de ninguna naturaleza (Guerrero, 2006): “la tortura es, por ello, sinónimo de inquisición” (Maier, 1989, p. 212). Atendiendo a estas valoraciones, no es difícil entender por qué se califica, de manera general, al proceso inquisitivo (y a todo lo que de él se derive) como prácticas abusivas, medievales, asimilando 'lo inquisitivo' con la vulneración inmediata de garantías procesales -0 , incluso, su ausencia completa- (Bachmaier, 2009), confundiendo así el concepto de proceso inquisitivo como momento histórico en Europa con la concepción actual de 'lo inquisitivo' como todo aquello diferente al sistema adversarial norteamericano (Montero, 2009; Schünemann, 2007).

Como elementos históricos del proceso inquisitivo -aunque no obligatorios desde un plano lógico- se mencionan la obligatoriedad de la acción penal (Zamora, 1993), el carácter público de los órganos encargados de la acusación y la obligación del juez de motivar sus decisiones (Ferrajoli, 1995). Aunque, se ha visto la obligatoriedad de la acción penal como una nota característica del proceso inquisitivo (Bachmaier, 2009).

En contraposición con el llamado proceso inquisitivo, el proceso acusatorio es identificado, desde el marco histórico, como el sistema originario -en relación con el sistema inquisitivo- (Armenta, 2004; Cuéllar et al, 2004), aunque también se le identifica como una reacción histórica al proceso inquisitivo (Zamora, 1993). Se identifica como un sistema primitivo (surgido en Grecia y en la Antigua Roma (Armenta, 2004; Cuéllar et al, 2004; Ferrajoli, 1995; González, 2001; Maier, 1989), donde el derecho penal y el derecho civil no estaban claramente diferenciados caracterizándose por ser relaciones privadas entre particulares (González, 2001); hay quien afirma, además, que es un sistema procesal característico de estados republicanos como los ya mencionados, o como el establecido en Francia después de la revolución de 1789 .

Se identifica el sistema acusatorio con la contienda de partes con intereses contrapuestos -a manera del proceso civil (Zamora, 1993)-, con la consecuente 
neutralidad del juez en la discusión procesal de tales partes (Armenta, 2004; Bovino, 2001a), aunque se habla indistintamente de sistema, función y principio acusatorio, sin entrar a definir ninguno de estos conceptos (Bovino, 2001a). El elemento identificador del proceso acusatorio, a lo largo de la historia, se encuentra en el establecimiento de un tercero imparcial (juzgador) que resuelve una cuestión jurídica atendiendo lo afirmado y probado por dos partes diferentes (Bachmaier, 2009). Esta última consideración tendrá consecuencias directas al momento de analizar el principio acusatorio.

Se afirma que la característica fundamental del sistema acusatorio es la división de los poderes que se ejercen en el proceso: el acusador, el acusado y el tribunal, quien decide (Ferrajoli, 1995; González, 2001; Maier, 1989). La acusación -reclamo o acción- y su contenido condicionan de manera directa la actuación del órgano juzgador y el sentido de su decisión final, característica esencial del sistema acusatorio (Maier, 1989; Pérez, 2001). El sistema acusatorio se edifica en torno a la idea de una contienda o debate de dos partes (juicio público) con un tercero imparcial (juez) que resolverá la contienda entre ellas (Pérez, 2001).

El sistema acusatorio se caracteriza por ciertos elementos: en primer lugar, se estructura con dos partes, claramente separadas y con intereses contradictorios, que deben resolver el conflicto a través de un juzgador neutral e inactivo (Bovino, 2001a; Pérez, 2001), generalmente conformado por jurados populares o colectivos (Maier, 1989). Existe una separación clara y rigurosa entre el juez y la acusación (Ferrajoli, 1995), condición calificada como 'necesaria' dentro de un sistema acusatorio (Carbonell y Ochoa, 2009).

Frente a esta conclusión, Montero Aroca critica con gran energía que el sistema adversarial norteamericano pueda ser calificado como acusatorio cuando el juez neutral -que debe caracterizar este sistema- no toma parte en la decisión final, sino que son los jurados quienes decidirán el conflicto penal (2008). Otra parte de la doctrina no encuentra reparo alguno en aceptar esta característica del sistema adversarial como propia del sistema acusatorio (Bovino, 2001a).

Baumann (1986) afirma por ello que no es posible hablar de que existan partes procesales en este caso, pues ello conllevaría a aseverar que tanto el acusador como el acusado tienen los mismos deberes, facultades y medios procesales, situación que se aleja de la realidad (el acusado, por ejemplo, no tiene ninguna obligación probatoria, mientras que el acusador sí).

Asímismo, en segundo lugar, la lucha de un interés particular (el correspondiente a cada parte procesal) juega un papel esencial en el sistema acusatorio (Maier, 1989). En tercer lugar, el acusador era, en algunos momentos históricos, privado; en otros momentos, era popular (Armenta, 2004; Bovino, 2005; Maier, 1989). Sin embargo, se afirma que, dentro de un sistema acusatorio, no es posible que el acusador sea parte de algún órgano público o que dependa del Estado (Bovino, 2005).

También, en cuarto lugar, la construcción de la verdad se da a través de la lucha o confrontación probatoria de las dos partes en el proceso (Bovino, 2001a). 
Ello significaba que el procedimiento era considerado un debate público entre las partes y el juzgador donde se practicaban los medios probatorios escogidos para cada una de las partes, teniendo el juzgador la obligación de decidir conforme tales pruebas (Maier, 1989).

En quinto lugar, debe decirse que para la construcción probatoria de la verdad procesal, las partes debían ser iguales; existía una igualdad entre el acusador y la defensa (Ferrajoli, 1995; Pérez, 2001); sin embargo, la carga de la prueba respecto de la culpabilidad del acusado recaía en la parte acusadora (Ferrajoli, 1995; Montañez, 2013). Además, en sexto lugar, se ha visto, también, que la oralidad y la publicidad son características del proceso acusatorio (Ferrajoli, 1995; González, 2001; Pérez, 2001). Y, para concluir, en séptimo y último lugar, respecto de la valoración de la prueba ésta se daba a través del sistema de íntima convicción (Maier, 1989).

Ferrajoli (1995), por su parte, hace una clara diferenciación entre lo que él considera elementos históricos que, de manera lógica, caracterizan el sistema acusatorio con aquellos otros elementos que no son esenciales al modelo acusatorio. Dentro del primer grupo incluye la separación entre el acusador y el juez, la igualdad entre las partes y la publicidad y la oralidad del proceso. Dentro del segundo grupo -elementos históricos, pero no esenciales-, incluye la discrecionalidad de la acción penal, el carácter electivo del juez y la exclusión de la obligación de motivar las decisiones por parte de los jurados.

Si estas son las diferencias que mantienen ambos sistemas procesales, ¿tendrán alguna similitud? Bovino (2001a) afirma que el objetivo de todo procedimiento penal (sea en un sistema acusatorio o en uno inquisitivo) es la averiguación de la verdad a efectos de la realización del derecho penal y de la consecuente respuesta del Estado frente a tal hecho. Así pues, "la única diferencia entre ambos modelos es instrumental, esto es, que sólo existe en la medida en que a través de distintos métodos se persigue un objetivo común" (Bovino, 2001a, p. 6). Pese a esta similitud, la averiguación de la verdad se consideraba desde distintos enfoques, pues mientras el proceso inquisitivo buscaba la verdad material, el proceso acusatorio intentaba conseguir una verdad formal, la verdad demostrada por las partes a través de las pruebas incorporadas (Montañez, 2013).

Vistas las características precedentes, no es extraño encontrar que el sistema acusatorio sea calificado como un 'verdadero proceso', en cuanto existe un juez imparcial e independiente y dos partes enfrentadas entre sí (González, 2001; Montero, 1994, 2008, 2009). Se afirma, además, que este sistema procesal protege el principio de igualdad procesal, el principio de contradicción y el derecho de defensa (Armenta, 2004).

Visto todo lo anterior, no queda clara la diferencia entre ambos sistemas procesales; y más allá de tales diferencias, debe resolverse si, en efecto, deben contraponerse ambos sistemas (Langer, 2001). Son varias las explicaciones dadas a tales dificultades teóricas. Por una parte, se afirma que la difícil tarea de diferenciar aquellos rasgos o elementos lógicamente necesarios de cada sistema procesal de 
aquellos otros que no lo son genera las dificultades para diferenciar ambos sistemas procesales (Ferrajoli, 1995):

Esta asimetría ha sido fuente de muchas confusiones, habiendo dado lugar a que a menudo fueran considerados como esenciales de uno u otro modelo teórico elementos pertenecientes de hecho a sus respectivas tradiciones históricas, pero lógicamente no necesarios en ninguno de los dos o compatibles con ambos. Como es obvio, la construcción teórica de los dos modelos y la decisión sobre lo que en ellos es esencial y lo que es, por el contrario, contingente, son ampliamente convencionales, apareciendo vinculadas tan sólo a la tendencial, es decir a la presencia de los elementos asumidos como constitutivos en las respectivas tradiciones históricas y, sobre todo, a su compatibilidad lógica [...] (Ferrajoli, 1995, p. 563).

Por otra parte, la confusión puede tener origen en la pretensión de la doctrina norteamericana (luego reiterada por la doctrina continental) de monopolizar el concepto de 'proceso acusatorio' para referirse al sistema adversarial establecido en Estados Unidos (Montero, 2008, 2009), todo ello ante la creencia equivocada de que tal sistema no sólo es el mejor, sino incluso que es el único posible dentro de un Estado de derecho, rechazando cualquier procedimiento penal diferente (Montero, 2009).

Se afirma, además, que el llamado proceso inquisitorio ni siquiera es un verdadero proceso (González, 2001; Montero, 1994, 2008, 2009; Pérez, 2001) -o por lo menos no puede calificársele así desde una perspectiva actual (Gómez, 2004; Pérez, 2001)_33 más que un proceso judicial, es una forma autodefensiva del Estado (Zamora, 1993). Y todo ello es así por cuanto no puede haber proceso judicial si no se respetan las garantías mínimas requeridas para su existencia (Pérez, 2001), si el acusador es al mismo tiempo el órgano de juzgamiento (Montero, 2008), reduciendo así toda la dificultad teórica para diferenciar el sistema acusatorio y el sistema inquisitivo en tal confusión. Hay un verdadero proceso cuando existe, así mismo, un juez imparcial que resolverá la controversia desarrollada por dos partes enfrentadas (González, 2001).

Montero Aroca (2006), por su parte, concluye que la pretendida diferencia entre lo acusatorio y lo inquisitivo no es respecto de dos sistemas procesales diferentes; son en realidad "dos sistemas de actuación del Derecho penal por los tribunales, de los cuales uno es extraprocesal, es decir, en el que no se utiliza el medio que es el proceso, y otro es procesal" (p. 922). Lo acusatorio y lo inquisitivo serían entonces formas para designar dos sistemas de actuación del derecho penal (Montero, 2008, 2009), dos modelos de organización judicial (Ferrajoli, 1995), o dos medios de evitar la comisión de delitos (Maier, 2001; Pérez, 2001), pero no dos sistemas pro-

\footnotetext{
${ }^{3}$ Sin embargo, Maier (2001) califica el proceso penal judicial como inquisitivo, para señalar el monopolio que ejerce el Estado en la persecución, investigación y castigo frente al delito, todo ello para contrastar este modelo de actuación del derecho penal frente al sistema composicional, donde son la víctima y el victimario quienes llegan a la solución del conflicto. Como puede verse, en este caso, 'proceso inquisitivo' es sinónimo de proceso judicial, contrariando la interpretación que aquí se señala.
} 
cesales penales. No es lo mismo -ni puede confundirse teóricamente- un enjuiciamiento penal a un proceso judicial penal, pues para la emisión de una sentencia no es necesaria la concurrencia de las partes en el primero, el segundo no será posible sin la participación de éstas y la necesaria independencia de quien tiene la función de juzgar (Briseño, 1970). El llamado proceso inquisitivo no es más que un sistema de actuación histórico del derecho penal que no tiene el carácter de proceso judicial (Montero, 2009). Por ello, se afirma que:

El denominado proceso inquisitivo no fue y, obviamente, no es, un verdadero proceso. Si éste se identifica como actus trium personarum, en el que ante un tercero imparcial comparecen dos partes ( $y$, por lo mismo, parciales) situadas en pie de igualdad y con plena contradicción, planteando un conflicto para que aquél los solucione actuando el derecho objetivo, algunos de los caracteres que hemos indicados como propios del sistema inquisitivo llevan ineludiblemente a la conclusión de que ese sistema no puede permitir la existencia de un verdadero proceso [...] (Montero, 1994, p. 530; 2006, p. 922).

Esta concepción del proceso inquisitivo como una forma de aplicación del derecho penal -pero no de un proceso judicial conforme al entendimiento actual de dicho concepto- ha sido explicado históricamente (Bachmaier, 2009), pues en el proceso inquisitivo lo importante era obtener los elementos de prueba -tarea asignada al juez-, dado que su valoración se daba a través de una tarifa legal que no podía desconocerse; así, cualquier debate que se hiciera después de recaudas las pruebas por el juez era inservible o inútil (Bachmaier, 2009). Por lo anterior, era innecesario, vista la lógica que se daba en tal sistema, un debate entre dos partes pues lo único relevante era la obtención de elementos de prueba.

Para esta parte de la doctrina (González, 2001; Montero, 1994, 2006), los así denominados 'sistemas procesales' son sólo formas de explicar -sin el rigor y la precisión necesarias (Guerrero, 2006) - cómo en la evolución histórica del derecho penal existieron épocas en las que la aplicación de este derecho no era del resorte único del Estado, en otras se aplicaba por órganos diferentes a los jurisdiccionales e incluso por medios diferentes al proceso judicial. La supuesta diferencia entre proceso inquisitivo y proceso acusatorio es resultado de un evidente error conceptual (Montero, 2006, 2009), pues en la actualidad es evidente que el proceso inquisitivo (como concepto que engloba una realidad histórica ya superada) no es una opción ni válida (Bachmaier, 2009) ni constitucional (Gómez, 2007).

Bovino (1998), implícitamente, reconoce esta última interpretación respecto del proceso acusatorio, pues afirma que sólo un modelo de enjuiciamiento penal que reconozca y respete los principios básicos y garantías establecidas en el proceso acusatorio puede ser aceptado en un Estado de derecho, debido a las bases ideológicas establecidas en las constituciones políticas: para él, proceso acusatorio parece ser un sinónimo de proceso judicial con plenas garantías procesales y constitucionales, tal como lo reconoce Montero Aroca (1994, 2006, 2008, 2009). 
Puede concluirse, en relación con la supuesta diferencia existente entre el proceso acusatorio y el inquisitivo, que tal diferencia no es más que:

[...] una falta de precisión conceptual en torno a lo que es proceso, pues sólo desde la misma ha podido concluirse que a un sistema de aplicación del Derecho penal tal y como antes hemos descrito puede llamársele procesal. Proceso inquisitivo es una contradictio in terminis, mientras que proceso acusatorio es un pleonasmo; el calificativo acusatorio no añade nada a la palabra proceso (Montero, 2006, p. 623).

Del análisis emprendido se deduce con toda claridad que lo importante no son realmente las diferencias entre un sistema procesal y el otro, pues ello son cuestiones de interés histórico (Bachmaier, 2009); más allá de estas divergencias, son los principios y las reglas procesales concretas las que determinan cómo se configura un proceso penal (Montero, 1994). E incluso, como cuestión histórica, la dicotomía entre 'lo acusatorio' y 'lo inquisitivo' debe replantearse, pues los análisis mantenidos hoy generan errores conceptuales (Bachmaier, 2009), aportando rasgos incompletos en la estructura general de ambos sistemas procesales; no es posible deducir conclusiones claras y coherentes sobre la estructura y los presupuestos filosóficos y procesales de cada sistema (Guerrero, 2006).

\section{¿Qué caracteriza al proceso acusatorio y, por ende, al principio acusatorio?}

La definición de principio acusatorio lleva en sí misma la necesidad de acudir al sistema adversarial, o eso es lo que se ha entendido desde la perspectiva de Europa y América Latina a través de las reformas procesales mantenidas los últimos años (Carbonell y Ochoa, 2009; Gómez, 2007; Montañés, 2001). Sin embargo, ya se ha visto la confusión existente para definir el concepto de 'proceso acusatorio' y diferenciarlo de su contraparte, el 'proceso inquisitivo'. Se suma, además de estas dificultades, el hecho de que la doctrina norteamericana no hable propiamente del principio acusatorio (Cuéllar et al, 2004; Gómez, 2007). ¿Qué es, entonces, el principio acusatorio?

Gómez (2007) afirma que la doctrina norteamericana entiende por sistema adversarial el único "sistema procesal para la actuación del Derecho Penal sustantivo, que para el mundo civilizado debería ser el único en realidad posible en una democracia" (p. 83). Se trataría de un proceso penal que tiene incorporadas todas las garantías necesarias para la protección de las partes, garantizando así el llamado due process of law (Gómez, 2007 y Gómez, Esparza, Planchadell, Pérez, Beltrán y Gánem, 2013). Pero, inexplicablemente, tal doctrina no habla del principio acusatorio dentro de tales garantías, y no lo hace, pues no es necesario: dentro del proceso adversarial, y a través del due process of law y el fairness se establece todo el conjunto necesario de garantías procesales (Gómez, 2007; Gómez et al, 2013).

Así pues, el principio acusatorio parece estar ya incorporado dentro de las demás garantías procesales que se reconocen en el sistema adversarial y, con igual contenido, en el sistema continental (Fernández, 1990; Gómez, 2007). Si ello es así, el contenido del principio acusatorio ya estaría incorporado en otras garantías 
procesales ya reconocidas por los sistemas procesales continentales y el problema sobre la definición de este concepto sería un asunto de designación o rotulo: “'Adversarial system' en los Estados Unidos de América es para mí también lo mismo que debe entenderse por 'sistema acusatorio' en España" (Gómez et al, 2013, p. 88).

Sin embargo, se ha pretendido afirmar que el principio acusatorio sólo puede deducirse o derivarse de un proceso acusatorio (Zamora-Pierce, 1993), con lo cual se evidencia la confusión ya señalada entre proceso acusatorio-adversarial y proceso inquisitivo-continental; si el concepto 'proceso acusatorio' equivale a un real proceso judicial -como lo entiende Montero (1994, 2006, 2008)-, es claro que sólo de un proceso judicial puede derivarse el principio acusatorio, no así de otros sistemas de actuación del derecho penal (Bachmaier, 2009; Pérez, 2001).

A pesar de que la tarea de precisar el alcance del principio acusatorio no es fácil, pues sus límites y su contenido específico se confunden con otros principios o garantías procesales (Montañés, 2001; Pérez, 2001), el principio acusatorio responde, o por lo menos debe hacerlo, a la forma como debe iniciarse un proceso judicial en materia penal y quién debe hacerlo, ello a través de la conformación de un órgano -necesariamente jurisdiccional- que sea un tercero imparcial (Montero, 2006). Si el debate es presupuesto lógico de un proceso judicial, este sólo puede existir a través de la participación de dos o más partes procesales enfrentadas a un órgano encargado de dirimir la discusión, esquema básico del cual surge el principio acusatorio (Briseño; Cuéllar et al, 2004).

De lo anterior queda claro que no puede confundirse, entonces, el llamado proceso acusatorio con el principio acusatorio, pese a las dificultades que puedan existir en precisar el contenido de este segundo concepto (Iñiguez, 2003; Pérez, 2001; Rodríguez, 2013), pues las palabras 'sistema acusatorio', 'proceso acusatorio' y 'principio acusatorio' "se están utilizando, primero, con muy distintos significados y, después, con falta de rigor técnico" (Montero, 2006, p. 917).

Siendo ambos conceptos diferentes (proceso acusatorio y principio acusatorio), uno debe ser más amplio que el otro (González, 2001; Pérez, 2001). Y ello es así por cuanto el sistema acusatorio contiene algunas características lógicamente necesarias [tal como lo afirmó Ferrajoli (1995)], dentro de las cuales se encuentran algunas exigencias derivadas del principio acusatorio; en el proceso acusatorio se da el principio acusatorio, pero éste no puede poseer todo el contenido asignado al primero (González, 2001; Pérez, 2001): “hay características que se predican como propias del sistema acusatorio que no tienen nada que ver con el principio acusatorio entendido éste en sus justos términos" (González, 2001, p. 112).

Se afirma que la existencia del principio acusatorio está directamente relacionada con el reconocimiento en un sistema procesal, de la necesidad de imparcialidad judicial $^{4}$ (Montero, 1994; Montero, Gómez y Barona, 2014; Pérez, 2001), entendida

${ }^{4}$ La doctrina, en términos generales, utiliza los conceptos "imparcialidad judicial" e "independencia judicial" como sinónimos al momento de definir qué se entiende por 
como aquella necesaria independencia de la función judicial de aquella otra función acusatoria en cabeza, también, del Estado (Alcalá-Zamora y Castillo, 1992; Pérez, 2001; Rodríguez, 2013), siendo una de las manifestaciones más importantes del proceso debido (Esparza, 1994; Fernández, 1990; Guerrero, 2000).

El principio acusatorio presupone, con necesidad, que el ejercicio de las funciones de investigación, de procedimiento preliminar y de enjuiciamiento sea realizado por diferentes órganos (Armenta, 2004; Carbonell y Ochoa, 2009; Guerrero, 2000; Montero, 1994; Montero, Gómez y Barona, 2014); por ello, Montero (1994, p. 544) asevera que "el fundamento del principio acusatorio es la imparcialidad del juzgador, en cuanto requisito determinante de la misma existencia del proceso". Del principio acusatorio surge, entonces, el debate entre dos partes dentro del proceso frente a un órgano de juzgamiento, a modo de un esquema trilateral (Bovino, 2005; Pérez, 2001).

Desde luego, existe una incompatibilidad entre la actividad de instruir (investigar los hechos presuntamente cometidos) y la actividad de juzgar (verificar tales hechos investigados, a efectos de tomar una decisión) (Bovino, 2005; Montero, 2006, 2008). El principio acusatorio se concretaría, entonces, en el ejercicio de las funciones de investigación y acusación por un sujeto diferente a aquel que realiza el juzgamiento (Armenta, 2004; Baumann, 1986; González, 2001; Guerrero, 2000; Moreno, Cortés y Gimeno, 2003; Rodríguez, 2013), aun cuando ambas funciones sean realizadas por órganos estatales (Bovino, 2005); el que juzga y el que acusa no deben ser, entonces, la misma persona (Bovino, 2005; Gómez, Planchadell, Pérez, Montoliu y Montesinos, 2010).

Y es que "la existencia de la acusación y el contenido de la misma no pueden provenir ni ser fijadas por el mismo órgano que después será el juzgador" (Montero, 1994, p. 538); por ello, es la parte acusadora la que determina el objeto del proceso sin injerencia alguna por parte del órgano juzgador (Cuéllar et al, 2004). Aquel órgano encargado de la función de acusar no puede ser quien, durante el proceso judicial, sea quien juzgue tal acusación (Armenta, 2004; Díaz, 2014; Molina, 2010); las funciones de acusación y de juzgamiento deben separarse, lo cual "no es algo propio de una clase de proceso (el llamado proceso acusatorio), sino que atiende a la esencia del proceso" (Montero, 2006, p. 932).

Con el principio acusatorio se evita, entonces, el peligro de que el juez sea parcial (Baumann, 1986). En últimas, se trataría de un principio judicial o de "conformidad orgánica" (principio instrumental (Bovino, 2005), más que de un principio procedimental (Montero, 1994); aunque se acepta su carácter procedimental en cuanto garantiza la imparcialidad del órgano juzgador en el caso concreto, atendidas las condiciones específicas del proceso y del acusado (Bovino, 2005; Montero, Gómez y Barona, 2014). A efectos de garantizar esta imparcialidad procesal entre el órgano de acusación y el órgano de juzgamiento, se debe respetar durante todo el

principio acusatorio (Bovino, 1998). Por ello, a lo largo de este artículo se utilizarán indistintamente tales expresiones. 
procedimiento el esquema actus trium personarum, exigencia que separa al juez de las dos partes enfrentadas en el proceso (González, 2001; Pérez, 2001; Rodríguez, 2013); la imparcialidad del juez es consecuencia de su independencia de las partes y del objeto del proceso (Aguiló, 1997; Montero, Gómez y Barona, 2014). Pero, tal esquema (que parte de la existencia de tres extremos procesales) puede estar excluyendo al sistema adversarial norteamericano, al incluir al jurado dentro de la relación juez-acusador-acusado (Gómez, 2007).

Al evitar que el órgano juzgador asuma funciones de acusación dentro del proceso penal se garantiza que este no prejuzgue su sentencia así como la decisión final sobre la responsabilidad penal del acusado, con lo cual no asume una posición de parte procesal y garantiza la correcta apreciación de los elementos probatorios dentro del desarrollo del juicio oral (Pérez, 2001). Ferrajoli afirma, por ello, que la separación entre el juez y el órgano de acusador es el elemento constitutivo más importante del sistema acusatorio, elemento estructural y lógico (1995). Tal separación implica; por una parte, una condición especial de imparcialidad referida al juez en relación con las partes, garantía orgánica que lo caracteriza; por otra parte, establece la carga probatoria en cabeza de la acusación, garantía procesal del juicio (Ferrajoli, 1995).

La garantía orgánica a la que se refiere Ferrajoli parece exigir la existencia de un Estado de derecho cuyo sistema constitucional establezca la división de poderes y el reconocimiento de los derechos humanos del acusado, pues no de otra forma puede el Estado ser acusador y juzgador en un proceso judicial y considerar imparcial su participación realizando ambas funciones (Zamora-Pierce, 1993), ello entendiendo el principio acusatorio como un principio de conformidad orgánica (Montero, 1994).

La doctrina es casi unánime en afirmar que la imparcialidad del órgano juzgador se garantiza separando dicha función de la acusación, ello entendiendo la imparcialidad desde un sentido objetivo, como característica abstracta (Gómez, 2007; Montero, 1994; Montero, Gómez y Barona, 2014). Pero, la imparcialidad también puede entenderse desde una perspectiva subjetiva, en tanto que esta se vea afectada cuando la persona que debe decidir una controversia procesal conoce de manera previa el contenido de tal proceso; el juez debe ser ajeno al conflicto y a los hechos que conocerá a través del proceso penal (Gómez et al 2010), exigiendo, de quien juzgará al acusado la ausencia de prejuicios, parcialidades o prejuzgamientos en su contra (Bovino, 1998; Montero, Gómez y Barona, 2014).

A pesar de las anteriores consideraciones, Díaz (2014) afirma que el principio acusatorio no se caracteriza por la llamada imparcialidad judicial; por el contrario, asevera que tal imparcialidad se ha confundido con la neutralidad procesal, elemento que sí puede derivarse del principio acusatorio. El concepto del principio acusatorio se reduce, de esta forma, a contenidos estrictamente probatorios. Sin embargo, esta interpretación del asunto no sólo es incorrecta -como se verá a continuación- sino incluso aislada, pues la doctrina es unánime al reconocer que la imparcialidad judicial es un elemento derivado necesariamente de este principio. 
Ahora bien, queda claro que el principio acusatorio es consecuencia de la necesaria imparcialidad del juzgador, siendo el primero fundamento-fin del segundo (Rodríguez, 2013). Pero, ¿cuál es el contenido de este principio acusatorio? Existen varios enfoques que responden, con diferentes rangos de amplitud, al contenido de este principio. Mientras alguna parte de la doctrina limita su alcance a cómo se determinan los hechos y las personas investigadas (Montero, 1994) a través de una distribución de roles y de las condiciones en las que se adelantará el enjuiciamiento penal, otra parte (Moreno, Cortés y Gimeno, 2003), amplía de manera considerable este enfoque.

Quienes amplían el alcance del principio acusatorio lo hacen a través de diferentes contenidos. Por una parte, se afirma que dentro del principio de acusación deben incluirse, además, el derecho de defensa del acusado, el derecho de contradicción (Carazo, 2014; Molina, 2010; Zamora-Pierce, 2009), e incluso la presunción de inocencia, el principio de doble instancia así como los principios de inmediación, publicidad y la prohibición de reformatio in peius (Armenta, 2004; Montañés, 2001; Moreno, Cortés y Gimeno, 2003). La obligación de que la decisión final que resuelve el proceso penal sea consecuencia directa de las pruebas practicadas dentro del mismo proceso es una consecuencia adicional que se ha querido deducir del principio acusatorio (Bovino, 1998).

Frente a esta expansión del alcance del principio acusatorio, debe analizarse si en efecto tales elementos hacen parte de este concepto. Por una parte, se plantea que el principio acusatorio incorpora el principio de contradicción pues este último busca el equilibrio entre las partes procesales en igualdad de condiciones, con lo cual se estaría desarrollando la imparcialidad e independencia buscada por el principio acusatorio (Zamora-Pierce, 2009). Sin embargo, debe decirse que los derechos de defensa, de contradicción y de igualdad entre las partes son derechos que se derivan de las relaciones procesales surgidas entre las partes, no de la imparcialidad necesaria del ente juzgador (Gómez, 2007; González, 2001; Montero, 2006): "correctamente entendidos el principio acusatorio y el principio de contradicción es manifiesto que se refieren a aspectos muy distintos de la actuación del Derecho penal en el caso concreto; el primero atiende al juzgador, el segundo a las partes" (Montero, 2006, p. 933).

El principio acusatorio regula la relación acusador-juzgador; los principios y los derechos que surgen de las relaciones procesales entre las partes -como el derecho de contradicción, el derecho de defensa, el derecho de igualdad procesal- (Cuéllar et al, 2004) no se derivan ni directa ni indirectamente del principio acusatorio (Montero, 2006, 2008). Puede sentirse como un contrasentido, pero la expansión del concepto 'principio acusatorio' puede estar generando, en realidad, que este se vacíe de todo contenido (Montero, 2008, 2009). Se ha extendido de tal manera el alcance del principio acusatorio que, hoy, se ha convertido en un presupuesto básico del proceso penal (Montañés, 2001). Se trata, sin dudarlo, de una imprecisión conceptual (Montero, 2009). 
A pesar de ello, se encuentran posiciones contrarias que afirman que tales presupuestos procesales tienen consecuencia directa en el principio acusatorio (Armenta, 2004; Bovino, 2001a), con lo cual, surge una gran disparidad de conceptos sobre el alcance preciso del principio acusatorio (Gómez, 2007). La jurisprudencia nacional (como se verá) e incluso la jurisprudencia constitucional española (Montañés, 2001; Pérez, 2001) toman partido por esta posición, incluyendo dentro del principio acusatorio toda este conjunto de garantías procesales.

Así pues, debe decirse que la incorporación de ciertos derechos o principios que surgen de las relaciones procesales entre las partes no pueden tener origen en el principio acusatorio, pues tales presupuestos no pueden surgir atendiendo el contenido mismo de este principio (Gómez, 2007; Pérez, 2001). Así lo expresa con claridad Montero (2006), quien afirma lo siguiente:

En los últimos tiempos hemos asistido a una gran confusión conceptual, con base en la cual todo el proceso penal se ha hecho depender de un llamado principio acusatorio, cuyos contornos no han quedado bien delimitados; se ha llegado así a decir, y por altas instancias jurisdiccionales, que es este principio el que provoca en el proceso la contradicción, o que es una amalgama en la que se mezclan todas las garantías del acusado en el proceso [...] (p. 939).

La incorporación del principio de contradicción, del principio de igualdad entre las partes y del principio de prohibición de reformatio in peius dentro del principio acusatorio puede ser una consecuencia de una confusión entre principio acusatorio y sistema acusatorio (Rodríguez, 2013). Debido proceso es un término más preciso para referirse a ese conjunto de garantías procesales diferentes a aquella reconocida por el principio acusatorio: la imparcialidad del órgano juzgador (Fernández, 1990; González, 2001; Pérez, 2001). Es un error atribuirle al principio acusatorio contenido del derecho de defensa o de contradicción (Bovino, 2005; Pérez, 2001), pues aún sin independencia entre las funciones de acusar y juzgar (sin imparcialidad judicial) puede respetársele al acusado, en un menor grado, un mínimo de defensa procesal (Bovino, 2005).

La misma crítica debe realizarse a aquellos intentos por incluir, como contenido del principio acusatorio, las garantías de publicidad que deben garantizársele al acusado -como el derecho de ser informado de la acusación- (Fernández, 1990), demostrando una confusión entre lo que es realmente acusatorio y lo que hace parte del núcleo de lo contradictorio (como principios diferentes); una cosa es la imparcialidad necesaria del órgano juzgador, y, otra muy diferente es la relación entre las partes procesales que debe respetar ciertos parámetros de lealtad e igualdad.

Incluso, se afirma que el principio acusatorio posee dentro del procedimiento penal una influencia considerable en la configuración de la prueba, de manera más precisa en la carga probatoria en cabeza del acusador (Ferrajoli, 1995) ${ }^{5}$. Esto

${ }^{5}$ Ferrajoli (1995) asigna, como consecuencia de la separación entre juez y acusador, el establecimiento de una carga probatoria en cabeza de este último, garantía procesal del juicio. 
último no deja de ser criticado por quienes entienden que todo el sistema de pruebas (legalidad, pertinencia, modos de incorporación, valoración, etc.) es un elemento propio del proceso que nada tienen que ver con la separación entre las funciones de acusación y juzgamiento (Montero, 2008). Igual crítica puede hacerse a quienes consideran que el principio acusatorio incluye la obligación del juez de decidir atendiendo sólo las pruebas practicadas e incorporadas dentro del proceso (Bovino, 1998).

Pero, y si el órgano que juzga puede decretar pruebas de oficio, ¿tal situación no pone en entredicho la separación esperada entre acusación y juzgamiento y la consecuente imparcialidad? Escenarios como este son altamente discutibles, pues no es claro si realmente el principio acusatorio tiene incidencia directa o al menos indirecta (Gómez, 2007). Pareciera que tal situación no afecta la imparcialidad del ente juzgador $-\mathrm{y}$ con ella, el principio acusatorio- pues son muchos los procedimientos penales europeos que aceptan dicha situación sin que se entienda afectada la garantía constitucional de imparcialidad judicial (Gómez, 2004; González, 2001; Montero, 2008). Entender que la incorporación de pruebas de oficio por parte del órgano juzgador afecta el principio acusatorio es confundir este con el principio dispositivo dentro del proceso civil, pues una es la imparcialidad que se deriva del principio acusatorio y otra es la existencia de intereses privados y particulares, derivados del principio dispositivo en materia procesal civil (Pérez, 2001).

Sin embargo, no todos comparten dicha opinión pues se afirma, por una parte, que la asignación de facultades probatorias adicionales al órgano juzgador ampliaría el papel decisorio que, de manera estricta, tendrían en un sistema acusatorio (Bovino, 2001a; Díaz, 2014); por otra parte, surge de la separación entre la función de acusar y la función de juzgar la necesidad de que sea el acusador quien pruebe la responsabilidad penal de la persona investigada (Ferrajoli, 1995), con lo cual podría argumentarse que, en efecto, del principio acusatorio podrían derivarse consecuencias respecto de la carga probatoria dentro del proceso penal.

Sin embargo, puede afirmarse que la aportación o introducción de pruebas de manera oficiosa no afecta de manera directa la imparcialidad del juzgador (él continuará siendo imparcial frente a las pretensiones de ambas partes aún con la introducción de pruebas de oficio), razón por la cual dicha circunstancia no afectaría al principio acusatorio (Bovino, 2005; Gómez, 2004; Pérez, 2001), aunque se ha reconocido que tal principio si debe disminuir, en cierta forma, las facultades procesales del juez encargado de juzgar al acusado (Montero, Gómez y Barona, 2014)

Además, se habla de que el sistema de justicia negociada -conformidad con la pena y con la culpabilidad por parte del acusado- afectan de manera directa el principio acusatorio (Almeyra, 1997; Anitua, 2009; Bovino, 2001b); entender que la justicia negociada afecta dicho principio es la consecuencia de una confusión entre un sistema acusatorio formal y uno material, pues sólo en el segundo -el acusador es un particular con pleno poder respecto de la acción penal-es posible considerar que la conformidad de la pena entre el acusador y el acusado es algo coherente con tal sistema procesal (Bovino, 2001b). 
Sin embargo, la fundamentación en este punto es superficial y no se logra precisar por qué figuras como el plea bargaining del sistema adversarial norteamericano afectan este principio, cuando al parecer tal sistema procesal puede caracterizarse como acusatorio. Incluso existe una doctrina que afirma todo lo contrario, estableciendo que el principio acusatorio en nada afecta la selección que haga el legislador respecto de la obligatoriedad de la persecución penal o el establecimiento de mecanismos de justicia negociada (Armenta, 2004); se llega, incluso, a afirmar que del modelo teórico acusatorio debe deducirse todo lo contrario, la obligatoriedad e irrevocabilidad de la acción penal (Ferrajoli, 1995).

Baumann (1986), por su parte, afirma que del principio acusatorio se deriva la calidad de parte procesal del acusado, imposibilitando que sea considerado objeto del proceso: al existir una imparcialidad entre el órgano acusador y el órgano de juzgamiento, el acusado se erige en parte procesal junto al acusador. Sin embargo, la calidad de parte procesal del acusado surge -como lo dice Montero $(2002,2006)$ de la existencia misma de un proceso judicial, no de la existencia del principio acusatorio. Este último punto es especialmente interesante, pues Gómez (2007 y 2013) asevera que el principio acusatorio pareciera derivarse -en el sistema adversarial- del due process of law y del fairness, con lo cual se concluye sin esfuerzos que el principio acusatorio se encuentra también en el proceso penal continental pues tales garantías también se encuentran allí reguladas (Fernández, 1990).

El principio acusatorio tendría, entonces, dos significados -según Gómez Colomer-: la exigencia de que todo proceso penal requiere la existencia de una acusación formulada por una persona diferente a quien asumirá funciones de juzgamiento, y la imposibilidad de alterar el objeto del proceso que se encuentra delimitado por la acusación hecha, en relación con los hechos y con las personas acusadas (2004).

Visto todo lo anterior, y tomando como punto de partida el hecho de que el principio acusatorio sólo presupone el requisito de imparcialidad del órgano juzgador (Bovino, 2005), es claro que la consagración de este principio en un proceso penal establece algunas garantías dentro del proceso que sólo pueden tener por objeto la protección de la imparcialidad del órgano juzgador (González, 2001); para el caso las siguientes:

En primer lugar, "no hay proceso sin acusación" (Pérez, 2001, p. 68). La existencia de un proceso penal presupone la existencia previa de una acusación (Baumann, 1986; Cuéllar et al, 2004; Esparza, 1994; Gómez, 2004; Montañés, 2001; Montero, 2008; Moreno, Cortés y Gimeno, 2003; Pérez, 2001). Se menciona también, como presupuesto del principio acusatorio, la existencia previa de una acción (Armenta, 2004).

Además, en segundo lugar, "la acusación debe ejercitarse por un órgano distinto del que ha de juzgar" (Montañés, 2001, p. 1), en el entendido de que "el que instruye no debe juzgar" (Bovino, 1998, p. 54). La acusación (como requisito previo de existencia del proceso penal) debe surgir de un órgano diferente a aquel que debe juzgar el comportamiento (Carbonell y Ochoa, 2009; Díaz, 2014; Esparza, 1994; 
Montañés, 2001; Moreno, Cortés y Gimeno, 2003; Pérez, 2001; Rodríguez, 2013). Frente a este punto, Montero (2008) aclara que es intranscendente si la función de acusar (o instruir) y aquella de juzgar correspondan, en ambos casos, a jueces pues en tal caso ambas funciones estarán asignadas a órganos diferentes, cumpliendo así con la separación de funciones pretendida por el principio acusatorio; la actividad de juzgamiento o de acusación puede ser desarrollada por jueces y cumplir, así mismo, con el principio acusatorio (Bachmaier, 2009).

En este punto surge una confusión, pues se afirma que si el órgano que instruye es el juez, se trata, con necesidad, de un proceso inquisitivo (Armenta, 2004), como lo entiende la doctrina norteamericana al momento de calificar los procedimientos penales europeos (Gómez et al, 2013). Con ello, se olvida que el principio acusatorio exige la separación de funciones dentro del proceso penal, no la imposibilidad de que el juez pueda instruir (Gómez, 2004; González, 2001; Montero, 2008): “Se trata, simplemente, de cosas distintas, por lo que nos parece que Juez Instructor y proceso penal acusatorio, en sentido europeo continental, son perfectamente compatibles" (Gómez, 2004, p. 3429).

En tercer lugar, la acusación es requisito de existencia del proceso penal, pero también límite estricto de la sentencia que lo resuelve, por cuanto la condena no puede superar los límites de la acusación formulada, ni respecto de los hechos ni de las personas acusadas (Armenta, 2004; Baumann, 1986; Esparza, 1994; Gómez, 2004; Montero, 2006; Ortells, 1993), ello pese a opinión en contrario (Pérez, 2001). Este límite entre la acusación y la sentencia que resuelve el proceso se ha denominado principio de congruencia (Moreno, Cortés y Gimeno, 2003). El acusador, entonces, fija el objeto preciso del proceso penal (Cuéllar et al, 2004; Montero, 2008).

Este principio de correlación entre la acusación y la sentencia (Montañés, 2001) debe analizarse desde su prohibición de exceso (el juez no puede excederse, en su decisión, respecto de lo solicitado por la parte acusadora), en el entendido que actuando de otra manera pondría en entredicho su imparcialidad (Carazo, 2014; Ortells, 1993), produciendo así una decisión sin acusación previa respecto de tales hechos o pretensiones (Montañés, 2001).

También, en cuarto lugar, el órgano que se encarga de juzgar dentro del proceso penal no puede tener poderes de dirección material que afecten su imparcialidad (Montero, 1994, 2006). De esta forma, el juez -como órgano juzgador- sólo puede tener facultades decisorias, generalmente pasivas dentro del debate procesal entre las partes (Bovino, 2005). Así mismo, en quinto lugar, el órgano que se encarga de acusar, dentro del proceso penal, debe tener la carga de la prueba respecto de la responsabilidad penal de la persona investigada (Ferrajoli, 1995).

Por el contrario, el principio acusatorio no incluye las siguientes consecuencias que han sido señaladas por la doctrina:

Primero, el principio acusatorio no puede incluir ni el derecho de contradicción, ni el derecho de defensa, ni mucho menos el derecho de igualdad entre las partes 
(Bachmaier, 2009; Bovino, 2005; Gómez, 2007; Montero, 1994; Pérez, 2001), pues tales principios procesales se derivan de las relaciones procesales entre las partes, no de los nexos entre el acusado y el órgano de juzgamiento (Montero, 2006, 2008). Todo esto, a pesar de lo que puede afirmar parte de la doctrina (Armenta, 2004; Carazo, 2014).

Segunda: a pesar de que no es un punto claro, el principio acusatorio tampoco excluiría la posibilidad de que el juez (órgano de juzgamiento) pueda decretar pruebas de oficio (Gómez, 2007). Es un punto altamente controvertido por la doctrina (Bovino, 2001a; Díaz, 2014), pero se reconoce que tal facultad procesal no afecta la imparcialidad del juez (Bovino, 2005; Gómez, 2004; Montero, 2008; Pérez, 2001).

Tercera: el principio acusatorio tampoco incluye -o excluye- la posibilidad de una justicia negociada a través de figuras procesales de conformidad con la pena y la responsabilidad penal (Rodríguez, 2013); las figuras procesales de justicia negociada no afectan la imparcialidad del órgano de juzgamiento, son un asunto de obligatoriedad, o no, de la acción penal, elemento que no afecta las relaciones del órgano juzgador con las partes.

Cuarta: la obligación de que la decisión final que resuelve el proceso penal sea consecuencia directa de las pruebas practicadas dentro del mismo proceso no puede ser una consecuencia deducida del principio acusatorio, a pesar de las opiniones diversas (Bovino, 1998). Es claro que todo el sistema de pruebas (legalidad, pertinencia, modos de incorporación, valoración, etc.) es un elemento propio del proceso, que nada tiene que ver con la separación entre las funciones de acusación y juzgamiento (Montero, 2008). De nuevo, existe una confusión y una expansión del alcance del principio acusatorio en este punto.

Así las cosas, para terminar este apartado puede decirse que el principio acusatorio puede ser calificado como 'el principio de principios' dentro del procedimiento penal, identificable con la esencia misma de un juez dentro de un Estado de derecho (Bovino, 2005). Ahora bien, establecido el alcance preciso del principio acusatorio, debe ahora analizarse si éste ha sido reconocido en nuestro ordenamiento jurídico y bajo qué extensión.

\section{El principio acusatorio en nuestro ordenamiento jurídico}

Para poder hablar del principio acusatorio en nuestro ordenamiento jurídico, lo primero que debe definirse es su concepto, ¿qué se entiende en Colombia por principio acusatorio? El principio acusatorio ha sido calificado de diversas formas: se le ha definido como un principio fundamental del Estado de Derecho (Corte Constitucional, Sentencia A-188A de 2005); se le ha otorgado el calificativo de ser la columna del "nuevo sistema de procesamiento [sic] penal" (Corte Suprema de Justicia, sentencias No. 33.254 de 2013 y No. 29.053 de 2008); e incluso se ha llegado a mantener que es la piedra angular del juicio (Corte Suprema de Justicia, sentencia No. 34.370 de 2010). 
La Corte Constitucional ha señalado que el principio acusatorio hace parte de los principios rectores de la administración de justicia (Sentencia C-540 de 2011). Pero, como puede verse, no se ha logrado concretar el concepto de este principio; no se sabe si es un elemento de un Estado de derecho, o un elemento del proceso, o una garantía procesal reconocida por el procedimiento penal. Incluso, se menciona y caracteriza el principio acusatorio sin siquiera definirlo (Corte Constitucional, Sentencia C-371 de 2011), lo cual demuestra las dificultades teóricas existentes para identificar, con precisión, en qué consiste el principio acusatorio en nuestro país.

Las dificultades teóricas no se limitan a la definición del principio acusatorio, sino que estas también se ven al momento de especificar el alcance de este concepto. La jurisprudencia colombiana, cuando habla del principio acusatorio, ha afirmado que la existencia de un tercero imparcial, que dirima los conflictos, es una parte indisoluble de un orden justo y de un Estado Social de Derecho (Corte Constitucional, Sentencia T-176 de 2008; Sentencia T-657 de 1998). Así, es claro que la primera consecuencia que deriva de la jurisprudencia del principio acusatorio es la necesaria imparcialidad judicial; del principio acusatorio se deriva la necesidad de separar el órgano que investiga y acusa de aquel otro que falla (Corte Constitucional, Sentencia C-591 de 2005; Sentencia C-762 de 2009; Sentencia C-025 de 2010; Corte Suprema de Justicia, sentencias No. 26.087 de 2007 y No. 39.886 de 2013).

El principio acusatorio exige, entonces, una separación estricta entre los actos de investigación y acusación (todos ellos en cabeza de la Fiscalía General de la Nación) y el acto de juzgamiento (en cabeza del juez de conocimiento) (Corte Suprema de Justicia, Sentencia No. 24.468 de 2006), llamando a dicha separación "la equidistancia del juez respecto de ambas partes" (Corte Suprema de Justicia, Sentencia No. 39.886 de 2013).

La separación de las funciones de investigación y acusación, en relación con aquellas otras de juzgamiento exige, además, no sólo la atribución de dichas actividades procesales a órganos diferentes (con lo cual se reconocería la imparcialidad objetiva), sino que también se excluiría la posibilidad de que el juez de conocimiento -quien conoce el proceso- tenga conocimiento previo de la acusación y de sus hechos (Corte Constitucional, sentencias C-545 de 2008 y C-540 de 2011), con lo cual se ha establecido una imposibilidad de que el juez de control de garantías que conoce el caso en la fase de investigación (a través del control constitucional de las actuaciones de investigación de la fiscalía) pueda ser a su vez el juez de conocimiento (Corte Constitucional, Sentencia C-762 de 2009).

Es claro, entonces, para la jurisprudencia nacional que el órgano que instruye no juzga (Corte Constitucional, Sentencia C-144 de 2010), con lo cual el juez ya no se encarga de adelantar la investigación penal (Corte Constitucional, Sentencia C-396 de 2007), ello acorde con el artículo 250 de la Constitución Política de Colombia. La jurisprudencia reconoce, sin duda, la necesidad de que las funciones de instrucción y de juzgamiento se hagan por separado, a través de órganos diferentes (Corte Constitucional, Sentencia C-545 de 2008). Hasta este punto, puede 
decirse que la interpretación realizada por la jurisprudencia nacional es correcta atendiendo el contenido asignado al principio acusatorio según la doctrina. Se ha afirmado que el artículo 250 de la Constitución Política de Colombia reconoce, de manera directa, la independencia que debe existir entre la función de juzgamiento y la función de acusación, asignando esta última función a la Fiscalía General de la Nación, con lo cual se respeta -hasta este punto- el principio acusatorio (Guerrero, 2000).

Sin embargo, la jurisprudencia le ha dado un alcance más amplio al principio acusatorio en Colombia, asignándole algunas consecuencias procesales. Como ya vimos, algunas de esas consecuencias sí tienen una vinculación directa con este principio, otras no. Se ha afirmado, de un lado, que del principio acusatorio se deriva la existencia necesaria de una acusación para la existencia de un proceso (Corte Suprema de Justicia, Sentencia No. 26.087 de 2007). Por ello, el juez no puede actuar si no existe una acusación por parte de la Fiscalía General de la Nación (Corte Constitucional, Sentencia C-1149 de 2001; Corte Suprema de Justicia, sentencias No. 26.309 de 2007; No. 34.370 de 2010; No. 36.907 de 2012 y No. 39.886 de 2013).

De otro lado, se ha derivado del principio acusatorio la correlación que debe existir entre la acusación y la sentencia (principio de congruencia) la cual surge de la vinculación judicial del juez al objeto del proceso (la acusación) (Corte Constitucional, Sentencia C-591 de 2005; Sentencia C-025 de 2010; Corte Suprema de Justicia, sentencias No. 34.370 de 2010 y No. 36.907 de 2012). Además, la jurisprudencia señala que del principio acusatorio surge la carga de la prueba de la responsabilidad penal, recayendo esta en el acusador (Corte Constitucional, Sentencia C-396 de 2007; Sentencia C-144 de 2010; Corte Suprema de Justicia, sentencias No. 26.087 de 2007 y No. 39.886 de 2013).

Pese a la interpretación mantenida hasta el momento (congruente con lo sostenido en este texto), la jurisprudencia incurre en el mismo yerro que alguna parte de la doctrina: expande el concepto del principio acusatorio, con lo cual una serie de garantías procesales, que nada tienen que ver con este, terminan derivando de su contenido. En este sentido, la Corte Constitucional ha incluido, dentro de las consecuencias procesales que se derivan del principio acusatorio, el principio de contradicción: "el principio acusatorio marca la pauta en la distribuciones de roles en el proceso penal" (Sentencia T-533 de 2001). En igual sentido, la Corte Suprema de Justicia, Sala de Casación Penal (Sentencias No. 24.468 de 2006 y No. 39.886 de 2013), ha afirmado que la igualdad de armas, como elemento del derecho de contradicción surge del principio acusatorio.

Se ha afirmado, de igual forma, que el derecho de defensa es una consecuencia del principio acusatorio (Corte Suprema de Justicia, sentencias No. 24.468 de 2006 y No. 34.370 de 2010). La prohibición de actividad probatoria respecto de juez de conocimiento (Corte Constitucional, Sentencia C-591 de 2005) y, en general, la pérdida de toda iniciativa probatoria (Corte Constitucional, sentencias C-144 de 2010 y C-396 de 2007) y todo impulso probatorio oficioso por parte del órgano 
juzgador (Corte Suprema de Justicia, Sentencia No. 29.415 de 2009) es una consecuencia probatoria y procesal derivada del principio acusatorio. Incluso, la jurisprudencia incluye dentro de los contenidos probatorios del principio acusatorio tanto el principio de inmediación procesal (Corte Suprema de Justicia, Sentencia No. 39.886 2013) como el derecho que tiene el procesado a conocer la acusación formulada (Corte Constitucional, Sentencia C-025 de 2010; Corte Suprema de Justicia, sentencias No. 26.087 de 2007; No. 26.309 de 2007 y No. 34.370 de 2010).

Dentro de esta interpretación incorrecta del principio acusatorio se pueden incluir las decisiones que derivan de este principio: la prohibición de la reformatio in pejus (Corte Constitucional, Sentencia T-533 de 2001; Sentencia C-591 de 2005; Sentencia C-025 de 2010; Corte Suprema de Justicia, Sentencia No. 26.087 de 2007). Incluso, la Corte Suprema de Justicia, Sala de Casación Penal (Sentencia No. 29.053 de 2008), ha incluido dentro del principio acusatorio la posibilidad de establecer mecanismos de justicia negociada -específicamente, las figuras de allanamiento a cargos y la celebración de acuerdos y preacuerdos con la Fiscalía- , demostrando así una confusión entre el principio acusatorio y el sistema adversarial norteamericano.

Las confusiones no se limitan a la jurisprudencia, pues la doctrina nacional también incluye dentro del principio acusatorio la prohibición por parte del juez de decretar pruebas de oficio y la prohibición de la reformatio in pejus (Díaz, 2014). Guerrero (2000) ha aseverado, por ejemplo, que en el proceso contemplado por la Ley 600 del 2000 se reconoce de manera directa el principio acusatorio en sus artículos 440, 441 y 442 cuando establece las formas de notificación, los requisitos sustanciales y las solemnidades de la resolución de acusación, marco general en el que deberá tramitarse el juicio, con lo cual parece incluir como consecuencias procesales, derivadas de este principio, la notificación de la acusación y los requisitos formales y materiales de esta, elementos que no hacen parte del principio acusatorio, tal como ya se analizó.

Parece que la jurisprudencia nacional incurre en la misma confusión demostrada en el punto en cuestión, respecto del real alcance del principio acusatorio; se le da, pues, un contenido y un desarrollo que no correspondería, en principio, con su real sentido, consecuencia de una confusión respecto del concepto acusatorio (Guerrero, 2000; Montero, 2006). En la misma confusión incurre no sólo la jurisprudencia nacional sino incluso la española (González, 2001; Montañés, 2001; Pérez, 2001), demostrando el estado caótico de la discusión y la incertidumbre respecto del concepto y el alcance específico del principio acusatorio.

\section{¿La existencia de un principio acusatorio es una necesidad procesal para la constitucionalidad del proceso penal en Colombia?}

Ahora bien, visto el contenido y el alcance dado al principio acusatorio, se debe responder el problema jurídico planteado al inicio de este texto: ¿la existencia de un principio acusatorio es una necesidad procesal para la constitucionalidad del proceso penal en Colombia? A tales efectos, el análisis de constitucionalidad se hará atendiendo lo contemplado por la Constitución Política de Colombia de 1991, 
así como por todos los tratados e instrumentos internacionales que puedan hacer parte del bloque de constitucionalidad (Organización de las Naciones Unidas [ONU], 1948, 1976; Organización de los Estados Americanos [OEA], 1969), pues sólo así podrá concluirse si, en efecto, el principio acusatorio es un presupuesto constitucional necesario dentro del proceso penal colombiano. De igual forma, el análisis emprendido se limitará a aquellas consecuencias procesales que sí se derivan del principio acusatorio; aquellas otras que no lo hacen, y que han sido interpretadas incorrectamente por la jurisprudencia nacional y por la doctrina -nacional y extranjera- no serán objeto de análisis.

La consagración de la imparcialidad judicial como un presupuesto necesario del proceso penal en la Constitución Política no es expresa, tal como lo ha reconocido la Corte Constitucional (Sentencia C-396 de 2007). Lo que sí ha determinado el Tribunal Constitucional (Sentencia T-319A de 2012) son las disposiciones constitucionales de las cuales se deriva la imparcialidad judicial como un 'principio iusfundamental'; en efecto:

En primer lugar, el debido proceso, derecho fundamental contemplado por el artículo 29 de la Constitución Política (Corte Constitucional, sentencias T-176 de 2008; C-545 de 2008; C-540 de 2011 y T-319A de 2012 y Corte Suprema de Justicia, Sentencia No. 34.370 de 2010). En segundo lugar, la independencia de las decisiones de la administración de justicia, conforme el artículo 228 del texto superior. (Corte Constitucional, sentencias A-039 de 2010 y T-319A de 2012).

En segundo lugar, en el artículo 230 de la Constitución Política, cuando se establece que los jueces sólo están sometidos al imperio de la ley (Corte Constitucional, Sentencia T-319A de 2012). También, en tercer lugar, se ha reconocido la constitucionalidad de la imparcialidad judicial a través de la protección de la igualdad material ante la ley, principio reconocido por el artículo 13 de la Constitución Política (Corte Constitucional, Sentencia C-037 de 1996; Sentencia C-540 de 2011).

La consagración constitucional de la imparcialidad judicial (como elemento que se deriva del principio acusatorio) no es directa, pero diversas disposiciones del texto constitucional reconocen su importancia. Pero, si hablamos de principio acusatorio como reconocimiento de la imparcialidad que debe tener el órgano de juzgamiento, todos los instrumentos internacionales reconocen, de manera clara y directa, dicha imparcialidad como componente del derecho a un justo proceso. El artículo 8.1 de la Convención Americana de Derechos Humanos reconoce el derecho de toda persona a ser juzgada por un tribunal independiente e imparcial (Organización de los Estados Americanos [OEA], 1969), con lo cual es claro que el principio acusatorio es reconocido por este instrumento internacional (Bovino, 1998).

De igual forma, el artículo $10^{\circ}$ de la Declaración Universal de Derechos Humanos afirma que toda persona humana tiene derecho a ser oída por un tribunal independiente e imparcial (Organización de las Naciones Unidas [ONU], 1948); en igual sentido, el artículo 14.1 del Pacto de Derechos Civiles y 
Políticos establece que toda persona tiene el derecho de ser oída públicamente por un tribunal independiente e imparcial (Organización de las Naciones Unidas [ONU], 1976). La Corte Constitucional ha afirmado que la imparcialidad judicial se reconoce directamente a través del bloque de constitucionalidad por medio de las disposiciones mencionadas (Corte Constitucional, Sentencia T-176 de 2008; Sentencia C-545 de 2008; Sentencia A-039 de 2010; Sentencia C-540 de 2011).

La incorporación de la imparcialidad judicial como componente del debido proceso y, por lo tanto, su carácter de presupuesto constitucional ha sido reconocida no sólo por la Corte Constitucional sino también por la Corte Interamericana de Derechos Humanos. Sobre el particular, la Corte ha afirmado que la imparcialidad judicial es un elemento o garantía fundamental del derecho al debido proceso (Castillo Petruzzi vs. Perú, 1999; Herrera Ulloa vs. Costa Rica, 2004), elemento que debe asegurar la objetividad del órgano juzgador, generando confianza entre las partes (Herrera Ulloa vs. Costa Rica, 2004). De tal forma, el juez (como órgano juzgador) no puede tener ningún interés o posición previa a la presentación de la controversia judicial (Iribarne vs. Chile, 2005; Barreto Leiva vs. Venezuela, 2009).

Así las cosas, nos encontramos frente a un escenario claro. No sólo la Constitución Política reconoce la existencia necesaria de un juez imparcial, sino también los instrumentos internacionales que hacen parte del bloque de constitucionalidad, con lo cual puede afirmarse que el principio acusatorio es una garantía esencial de todo Estado de derecho (Bovino, 1998).

\section{Conclusión}

No puede discutirse, visto todo lo anterior, la existencia de una confusión teórica respecto de los conceptos acusatorio e inquisitivo; y con ello, del concepto de principio acusatorio (Bachmaier, 2009). Pese a que es reiterada la doctrina que afirma la validez y la conveniencia de tal dicotomía (Anitua, 2009; Armenta, 2004; Bovino, 1997, 2001a; Carbonell y Ochoa, 2009; Damaska, 1998; Iñiguez, 2003; Langer, 2001), en realidad se trata de una discusión estéril, inútil e incluso ampliamente contradictoria (Schünemann, 2007); parece que cada autor tiene un concepto diferente de aquello que entiende por acusatorio, por lo cual concluye de manera diferente a los demás.

Además, la dicotomía planteada entre lo acusatorio y lo inquisitivo incurre en incoherencias lógicas que afectan la comprensión de dichos conceptos que obedecen a los diversos sentidos en lo que se manejan estos conceptos (Langer, 2001), pues ellos son analizados desde perspectivas históricas (lo que fue el sistema acusatorio o inquisitivo en el pasado), valorativas (lo que debería ser el sistema acusatorio o inquisitivo como sistema procesal), ideales (el modelo ideal de sistema acusatorio o inquisitivo según una valoración personal), e incluso normativas (si alguna figura procesal se adecua -acusativa- o no -inquisitiva- con el marco constitucional de un Estado) (Langer, 2001). 
La comprensión de 'lo acusatorio', desde una perspectiva histórica, tiene aún hoy día un significado teórico en la medida en que describe el desarrollo evolutivo del proceso penal (o más específicamente, de las formas de actuación del derecho penal), dentro de la historia de la cultura jurídica occidental. Pero, actualmente no es conveniente analizar el concepto acusatorio desde una perspectiva normativa o valorativa (Langer, 2001).

En fin, si se entiende que el principio acusatorio exige -0 , mejor, garantiza- que el órgano acusador sea diferente al órgano juzgador, y sólo eso, puede afirmarse que en efecto todo proceso penal debe ser acusatorio (Montero, 2008). Y tal vez a la misma conclusión llega la doctrina norteamericana respecto del sistema adversarial, pues ellos entienden que sólo su sistema puede ser aceptado en una democracia y en un Estado de derecho (Gómez, 2007; Gómez et al, 2013), procedimiento penal que se identifica -entre otros elementos- por la separación de las funciones de acusación y de juzgamiento, desarrolladas por órganos diferentes, todo ello a través del due process of law (Gómez, 2007; Gómez et al, 2013). Este mismo conjunto de garantías procesales incluye, también, el proceso penal continental a través de las figuras del debido proceso legal (Gómez et al, 2013), con lo cual cambian los nombres de los conceptos, pero parece que la conclusión es la misma: ambos procedimientos penales son procesos judiciales en la medida en que tienen separadas esas funciones (acusar y juzgar); si no fuera así, ni siquiera podríamos hablar de procedimiento judicial.

El llamado principio acusatorio pareciera ser, entonces, un mero "eslogan político" (Montero, 2008, p. 27), "comodín" (González, 2001, p. 113) o "bandera" (Bachmaier, 2009, p. 173), con lo cual 'lo acusatorio' (como elemento valorativo) incorpora todo aquello que garantice las mayores garantías procesales (Bachmaier, 2009), siendo así el medio que puede lograr todos los fines buscados por el legislador con las reformas legislativas incorporadas a los procedimientos judiciales nacionales (Carbonell y Ochoa, 2009; González, 2001); se entiende que sólo es posible un proceso acusatorio en un Estado de derecho, rechazando cualquier figura que pueda ser calificable como inquisitivo (Carbonell y Ochoa, 2009; Molina, 2010). Por ello:

Se ha hablado y se sigue hablando del "debido proceso", del "proceso justo", de "proceso acusatorio" e incluso de "sistema acusatorio", expresiones todas ellas que si se entienden como políticas pueden admitirse, pero que carecen de verdadero contenido técnico jurídico, pues en el fondo todas ellas se refieren a algo muy simple: el Derecho penal debe aplicarse por medio de un verdadero proceso o, si se prefiere y para decirlo más sencillamente: El Derecho penal se aplica sólo por medio del proceso [...] (Montero, 2006, p. 296).

Si es verdad que el concepto 'proceso acusatorio' es una confusión con la cual sólo se quiere señalar la necesidad de que el Derecho penal sea aplicado mediante un proceso judicial (González, 2001; Montero, 1994, 2006, 2008, 2009), es claro que esta es una exigencia de cualquier Estado de derecho (Bovino, 2005; Molina, 2010); el derecho penal sólo puede aplicarse mediante un proceso judicial 
que cumpla con las garantias procesales establecidas por la Constitución y la ley (Gómez, 2003), con lo cual proceso judicial y principio acusatorio parecen ser y exigir lo mismo (González, 2001).

Así, si el principio acusatorio exige la separación entre la función de acusación y de juzgamiento, tal requisito de imparcialidad es deducido de la Constitución Política (de manera indirecta) a través de los artículos 13, 29, 230 y 228 acorde con lo establecido por la propia Corte Constitucional (Corte Constitucional, Sentencia T-176 de 2008; Sentencia C-540 de 2011). Además, su consagración constitucional es directa a través del bloque de constitucionalidad (artículo 93 del texto superior), a través del artículo 8.1 Convención Americana de Derechos Humanos (Organización de los Estados Americanos [OEA], 1969), del artículo $10^{\circ}$ de la Declaración Universal de Derechos Humanos (Organización de las Naciones Unidas [ONU], 1948), y del artículo 14.1 del Pacto de Derechos Civiles y Políticos (Organización de las Naciones Unidas [ONU], 1976).

Es claro, por lo tanto, que el principio acusatorio sí es un presupuesto constitucional necesario del procedimiento penal en Colombia, acorde con el contenido asignado al principio en este texto, y de la interpretación realizada por parte de la Corte Constitucional. Se deben, pues, repetir las palabras de Bachmaier (2009, p. 175) frente a la dicotomía entre 'lo acusatorio' y 'lo inquisitivo':

El debate actual no puede definirse ya en términos de "acusatorio" frente a "inquisitivo", ni tampoco puede anclarse en la defensa del acusatorio, pues ello no contribuye a identificar con precisión cada uno de los problemas que afectan a la justicia penal. Toda reflexión sobre el proceso penal ha de realizarse primordialmente desde el enfoque de los derechos fundamentales y del contrapeso de poderes, sin olvidar el elemento de la eficacia [...].

\section{Referencias}

Acto Legislativo 03 del 2002. Por el cual se reforma la Constitución Política Nacional. Diario Oficial $N^{\circ}$ 45.040. Congreso de la República de Colombia, diciembre de 2002.

Aguiló, J. (1997). Independencia e imparcialidad de los jueces y argumentación jurídica. Isonomía, (6), 71-79.

Alcalá-Zamora y Castillo, N. (1992). Preocupaciones y directivas fundamentales del derecho procesal contemporáneo. En N. Alcalá-Zamora y Castillo, Estudios de teoría general e historia del proceso (1945-1972) (Tomo II, pp. 113-137). Ciudad de México: Universidad Nacional Autónoma de México.

Almeyra, M. Á. (1997). ¿Juicio abreviado o la vuelta al inquisitivo? Revista sumplemento de jusriprudencia penal. La Ley, 357-380. 
Anitua, G. I. (2009). La importación de mecanismos consensuales del proceso estadounidense, en las reformas procesales latinoamericanas. Cátedra Hendler, Facultad de Derecho, Universidad de Buenos Aires, Buenos Aires, Argentina.

Armenta, T. (2004). Nuevo proceso penal: sistemas y valoración de pesos y contrapesos. Criminalia: revista de las ciencias penales, (1), 253-269.

Barreto Leiva vs. Venezuela (2009). Serie C No. 206. Sentencia de fondo, reparaciones y costas. Corte Interamericana de Derechos Humanos.

Bachmaier, L. (2009). Sistemas procesales: La hora de superar la dicotomía acusatorio-inquisitivo. Revista del Instituto de Ciencias Jurídicas de Puebla, (24), 172-198. Recuperado de http: / / www.redalyc.org / articulo.oa?id=293222968008

Baumann, J. (1986). Derecho Procesal Penal. Conceptos fundamentales y principios procesales (Trad. C. Finzi). Buenos Aires: Depalma.

Bovino, A. (1997). La persecución penal pública en el derecho anglosajón. Revista Pena y Estado, (2), 13-84.

Bovino, A. (1998). Problemas del derecho procesal penal contemporáneo. Argentina: Editores del Puerto.

Bovino, A. (2001a). Ingeniería de la verdad. Procedimiento penal comparado. Revista de la Asociación de Ciencias Penales de Costa Rica, (19), 4-15.

Bovino, A. (2001b). Procedimiento abreviado y juicio por jurados. En J. Maier, \& A. Bovino, El procedimiento abreviado (pp. 51-96). Buenos Aires: Editorial Del Puerto.

Bovino, A. (2005). Principios políticos del procedimiento penal. Buenos Aires: Editores del Puerto.

Briseño, H. (1970). El Principio Acusatorio en el Proceso Penal. Jurídica-Anuario, (2), 47-108. Recuperado de http://juridicas.unam.mx/publica/rev/indice. htm? $\mathrm{r}=$ jurid\&n$=2$

Carazo, M. J. (2014). Apuntes jurisprudenciales sobre el principio acusatorio y su aplicación por el tribunal constitucional y el tribunal europeo de derechos humanos. Revista de Estudios Jurídicos, (14), 1-12.

Carbonell, M., y Ochoa, E. (2009). El derecho comparado frente a las reformas legislativas. El caso de Chile. Revista de Derecho, (32), 271-305.

Castillo Petruzzi vs. Perú (1999). Serie C No. 59. Sentencia de fondo, reparaciones y costas. Corte Interamericana de Derechos Humanos.

Constitución Política (1991). Congreso de la República de Colombia. Colombia. 
Cuéllar, R., Ferrera, D., López, E., Gómez, J-L., y Fernández, J. (2004). Derecho procesal penal de Honduras: manual teórico-práctico. Tegucigalpa, Honduras: Corte Suprema de Justicia.

Damaska, M. (1998). Aspectos globales de la reforma del proceso penal. En Reformas a la justicia penal en las Américas (pp. 12-21). Memorias de la primera conferencia organizada por DPLF. Washington, D.C.: DPLF.

Díaz, A. (2014). El principio acusatorio en el modelo adversarial colombiano. Análisis en torno a su aplicación. Cuadernos de Derecho Penal, (11), 35-87.

Esparza, I. (1994). El principio del debido proceso (Tesis doctoral). Universidad Jaume I de Castellón. Castellón de la Plana, España.

Fernández, R. (1990). Garantías constitucionales del proceso penal. Revista del Centro de Estudios Constitucionales, (6), 57-108.

Ferrajoli, L. (1995). Derecho y razón. Teoría del garantismo penal. Madrid: Editorial Trotta.

Gómez, J-L. (2003). La investigación del crimen en el proceso penal ante el Tribunal Penal Internacional. Revista Penal, (12), 72-97.

Gómez, J-L. (2004). Alternativas a la persecución penal y principio de legalidad. Estudios Jurídicos, 3416-3442.

Gómez, J-L. (2007). Hacia una nueva Ley de Enjuiciamiento Criminal acusatoria pura española: pros y contras del modelo. Revista Penal, (20), 74-88.

Gómez, J-L., Esparza, I., Planchadell, A., Pérez, M. Á., Beltrán, A., y Gánem, E. (2013). Introducción al proceso penal federal de los Estados Unidos de Norteamérica. Valencia: Tirant lo Blanch.

Gómez, J-L., Planchadell, A., Pérez, M. Á., Montoliu, B., y Montesinos, A. (2010). Introducción al Derecho Procesal. Parte General del Derecho Jurisdiccional. España: Universidad Jaume I de Castellón.

González, A. (2001). Correlación entre acusación y sentencia penal. Tenerife: Universidad de La Laguna.

Guerrero, Ó. (2000). Colombia. En J. Maier, K. Ambos, \& J. Woischnik, Las reformas procesales penales en América Latina (pp. 197-267). Buenos Aires: Editorial AdHoc.

Guerrero, Ó. (2006). El dificil encuentro entre el proceso penal anglosajón y el proceso penal continental. En Konrad-Adenauer-Stiftung E.V. Anuario de Derecho Constitucional Latinoamericano, (Tomo II, pp. 1047-1069). Uruguay. 
Herrera Ulloa vs. Costa Rica (2004). Serie C No. 107. Sentencia de excepciones preliminares, fondo, reparaciones y costas. Corte Interamericana de Derechos Humanos.

Iñiguez, P. (2003). La víctima: aspectos sustantivos y procesales. Alicante: Universidad de Alicante.

Langer, M. (2001). La dicotomía acusatorio-inquisitivo y la importación de mecanismos procesales de la tradición jurídica anglosajona. En J. Maier, \& A. Bovino, El procedimiento abreviado. Buenos Aires: Editorial Del Puerto.

Ley 906 de 2004. Por la cual se expide el Código de Procedimiento Penal. Diario Oficial No. 45.658. Congreso de la República de Colombia, Agosto de 2004.

Maier, J. (1989). Derecho procesal penal argentino (Tomo I. Vol. b). Buenos Aires, Argentina: Editorial Hammurabi.

Maier, J. (2001). Entre la inquisición y la composición. En L. A. Arroyo Zapatero, \& I. B. Gómez de la Torre, Homenaje al dr. Marino Barbero Santos : "in memorian" (Vol. 2, pp. 801-814). España: Universidad de Castilla-La Mancha y Universidad de Salamanca.

Molina, R. (2010). La conformidad en el proceso penal. España: Facultad de Derecho, Departamento de Derecho Penal y Procesal. Universidad de Sevilla.

Montañés, M. (2001). Las garantías constitucionales del proceso penal: El principio acusatorio. Repertorio Aranzadi del Tribunal Constitucional, (1), 1965-2002.

Montañez, J. (2013). Las negociaciones en el proceso penal: del procedimiento inquisitivo a la prisionización masiva. Revista Derecho Penal y Criminología, 34, (97), 65-83.

Montero, J. (1994). La garantía procesal penal y el principio acusatorio. La Ley: Revista jurídica española de doctrina, jurisprudencia y bibliografía, (1), 973-984.

Montero, J. (2006). El significado actual del llamado principio acusatorio. En J. L. Gómez et al, Terrorismo y Proceso Penal Acusatorio (pp. 311 y ss). Valencia: Tirant lo Blanch.

Montero, J. (2008). Principio acusatorio y prueba. En J. L. Gómez et al, Prueba y proceso penal. Valencia: Tirant lo Blanch.

Montero, J. (2009). Proceso penal y libertad. Ensayo polémico sobre el nuevo proceso penal. Madrid: Thompson Civitas.

Montero, J., Gómez, J. L., y Barona, S. (2014). Derecho Jurisdiccional I. Parte General (22 ed.). Valencia: Tirant lo Blanch.

Moreno, V., Cortés, V., y Gimeno, V. (2003). Introducción al derecho procesal (4a ed.). Valencia: Tirant lo Blanch. 
Organización de las Naciones Unidas [ONU]. (1948). Declaración Universal de Derechos Humanos. Paris. Recuperado de https://www.un.org/es/ documents/udhr/

Organización de las Naciones Unidas [ONU]. (1976). Pacto Internacional de Derechos Civiles y Políticos. Nueva York. Recuperado de http:/ / www2.ohchr. org/spanish/law/ccpr.htm/

Organización de los Estados Americanos [OEA]. (22 de Noviembre de 1969). Convención Americana sobre Derechos Humanos. Pacto de San José de Costa Rica. Costa Rica. Recuperado de http:/ / www.oas.org/dil/esp/tratados_B-32_ Convencion_Americana_sobre_Derechos_Humanos.pdf

Ortells, M. (1993). Revisión crítica de las nuevas tendencias sobre correlación entre acusación y sentencia en derecho español, con un breve epílogo sobre el derecho mexicano y el código procesal penal modelo para iberoamérica. Publicación del Instituto de Investigaciones Jurídicas UNAM, (87), 435-473.

Parabana Iribarne $v$ s. Chile (2005). Serie C No. 135. Sentencia de fondo, reparaciones y costas. Corte Interamericana de Derechos Humanos.

Pérez, M. (2001). Problemas que plantea el acusatorio en el actual proceso penal. Colegio de Abogados de la Región de Murcia, (30), 49-90.

Rodríguez, M. (2013). Sistema acusatorio de justicia penal y principio de obligatoriedad de la acción penal. Revista de Derecho de la Pontificia Universidad Católica de Valparaíso, (40), 643-686.

Schünemann, B. (2007). Sistema penal acusatorio. Aspectos problemáticos. Revista Iusta, (27), 111-125.

Sentencia C-037 (1996, febrero 5). Demanda de Inconstitucionalidad. M.P. Vladimiro Naranjo Mesa. Corte Constitucional.

Sentencia C-1149 (2001, octubre 31). Demanda de Inconstitucionalidad. M.P. Jaime Araujo Renteria. Corte Constitucional.

Sentencia A-188A (2005, septiembre 8). M.P. Humberto Antonio Sierra Porto. Corte Constitucional.

Sentencia C-591 (2005, junio 9). Demanda de Inconstitucionalidad. M.P. Clara Inés Vargas Hernández. Corte Constitucional.

Sentencia C-396 (2007, mayo 23). Demanda de Inconstitucionalidad. M.P. Marco Gerardo Monroy Cabra. Corte Constitucional.

Sentencia C-545 (2008, mayo 28). Demanda de Inconstitucionalidad. M.P. Nilson Pinilla Pinilla. Corte Constitucional. 
Sentencia C-762 (2009, octubre 29). Demanda de Inconstitucionalidad. M.P. Juan Carlos Henao Pérez. Corte Constitucional.

Sentencia A-039 (2010, febrero 22). M.P. Luis Ernesto Vargas Silva. Corte Constitucional.

Sentencia C-025 (2010, enero 27). Demanda de Inconstitucionalidad. M.P. Humberto Antonio Sierra Porto. Corte Constitucional.

Sentencia C-144 (2010, marzo 3). Demanda de Inconstitucionalidad. M.P. Juan Carlos Henao Pérez. Corte Constitucional.

Sentencia C-371 (2011, mayo 11). Demanda de Inconstitucionalidad. M.P. Luis Ernesto Vargas Silva. Corte Constitucional.

Sentencia C-540 (2011, julio 6). Demanda de Inconstitucionalidad. M.P. Jorge Ignacio Pretelt Chaljub. Corte Constitucional.

Sentencia 24.468 (2006, marzo 30). Casación. M.P. Edgar Lombana Trujillo. Sala de Casación Penal, Corte Suprema de Justicia.

Sentencia 26.087 (2007, febrero 28). Casación. M.P. Marina Pulido de Barón. Sala de Casación Penal, Corte Suprema de Justicia.

Sentencia 26.309 (2007, abril 25). Casación. M.P. Yesid Ramírez Bastidas. Sala de Casación Penal, Corte Suprema de Justicia.

Sentencia 29.053 (2008, noviembre 5). Casación. M.P. José Leonidas Bustos Martínez. Sala de Casación Penal, Corte Suprema de Justicia.

Sentencia 29.415 (2009, febrero 4). Casación. M.P. Julio Enrique Socha Salamanca. Sala de Casación Penal, Corte Suprema de Justicia.

Sentencia 34.370 (2010, diciembre 13). Casación. M.P. Sigifredo Espinosa Pérez y Alfredo Gómez Quintero. Sala de Casación Penal, Corte Suprema de Justicia.

Sentencia 36.907 (2012, febrero 1). Casación. M.P. Julio Enrique Socha Salamanca. Sala de Casación Penal, Corte Suprema de Justicia.

Sentencia 39.886 (2013, octubre 13). Casación. M.P. José Leonidas Bustos Martínez. Sala de Casación Penal, Corte Suprema de Justicia.

Sentencia 33.254 (2013, febrero 27). Casación. M.P. José Leonidas Bustos Martínez. Sala de Casación Penal, Corte Suprema de Justicia.

Sentencia T-176 (2008, febrero 21). Acción de tutela. M.P. Mauricio González Cuervo. Corte Constitucional.

Sentencia T-319A (2012, mayo 3). Acción de tutela. M.P. Luis Ernesto Vargas Silva. Corte Constitucional. 
Sentencia T-533 (2001, mayo 21). Acción de tutela. M.P. Jaime Córdoba Triviño. Corte Constitucional.

Sentencia T-657 (1998, noviembre 11). Acción de tutela. M.P. Carlos Gaviria Díaz. Corte Constitucional.

Zamora, J. (1993). El principio acusatorio. Revista del Instituto Colombiano de Derecho Procesal, (14-15), 75-84.

Zamora, J. (2009). Justicia alternativa en materia penal. Themis, 117-157.

Zepeda, G. (2005). Algunas modalidades del principio de oportunidad en las reformas penales de América Latína: Lecciones prácticas para México. En S. García Ramírez, Derecho Penal, Memorias del Congreso Internacional de Culturas y Sistemas Jurídicos Comparados (pp. 251-283). México D.F.: Instituto de Investigaciones Jurídicas (UNAM). 